\title{
Syskonjordbruk i tio socknar
}

I de två föregående kapitlen har det gått att skönja ett mönster där det gradvis under 1900-talet blev vanligt att syskon sammanbodde och ofta även ägde gården gemensamt. Det är dock svårt att utifrån olika kvalitativa omdömen dra säkra slutsatser om vilka konkreta fall som åsyftas och hur hushållen var sammansatta. Det är därför oklart om företeelsen var ungefär densamma under perioden eller om den förändrades. För att komma vidare krävs både mer detaljerade uppgifter och att analysen utsträcks till en längre tidsperiod.

Vid sidan om officiell statistik och nationella enkätsvar finns, så vitt känt, inget källmaterial som gör det möjligt att dra tillförlitliga slutsatser om syskonjordbrukens omfattning och kännetecken på nationell nivå. I det här kapitlet tillämpar jag därför ett annat tillvägagångssätt och bearbetar uppgifter från flera olika källor om ett stort antal jordbrukarhushåll. På så sätt kan jag teckna en sammansatt bild av syskongårdarnas särdrag och blottlägga variationer och mönster inom gruppen. Det övergripande syftet i det här kapitlet är att identifiera hur vanliga syskonjordbruken var, hur de var sammansatta och vad som var utmärkande för dem.

\section{Tvärsnitt med kombinerade material}

För att undersöka syskonhushållens antal och kännetecken vore det idealiskt med ett källmaterial som gjorde det möjligt att både identifiera dem och följa gården och hushållets medlemmar över tid. Något sådant material existerar dock inte. Fastighetsbeteckningar som möjliggör jämförelser av samma enhet över tid infördes först 1908 och i jordbruksstatistiken kan enskilda enheter inte identifieras tillfredsställande förrän på 1930-talet. ${ }^{368}$ För äldre tid 
framgår hushållsdata främst av kyrkans folkbokföring, men eftersom den är löpande förd är det svårt att erhålla en ögonblicksbild av förhållandena. ${ }^{369}$ De årligt upprättade mantalslängderna ger mer av en ögonblicksbild, men de innehåller å andra sidan inte alltid yrkesbeteckningar och sällan uppgifter om släktskapsförhållanden inom hushållet. För att kunna närma sig syskonjordbruken är det alltså nödvändigt att kombinera flera typer av källor.

Under 1900-talets första decennier fanns i Sverige drygt 300000 jordbruksenheter och att undersöka samtliga är naturligtvis en omöjlighet. ${ }^{370}$ För att ge undersökningen skärpa och djup har jag begränsat mig till jordbrukarhushåll i tio socknar under drygt 120 år. Analysen utgår från tvärsnitt av samtliga områden vid sju tidpunkter med ungefär tjugo års mellanrum: 1870, 1890, 1910, 1930, 1945, 1971 och 1991. Vid varje nedslagsår har jag granskat samtliga jordbrukarhushåll och identifierat syskonjordbruken. För de fem första årtalen bygger granskningen på de församlingsutdrag som från 1860 låg till grund för Statistiska centralbyråns folkräkningar. ${ }^{371}$ Utdragen ger en ögonblicksbild av församlingsböckerna och innehåller upplysningar om hushållsstruktur, yrkesbeteckningar och eventuella släktskapsförhållanden inom hushållet. ${ }^{372}$ Från och med 1950 års folkräkning ersattes församlingsutdragen med uppgifter från mantalslängderna, vilkas oklara yrkesbeteckningar och knapphändiga familjeuppgifter försvårar analysen väsentligt. Av dessa skäl har folkräkningen för 1945, den sista enligt den äldre modellen, valts framför den för 1950. För de två nedslagsåren 1971 och 1991 har mantalslängdernas uppgifter kombinerats med data från Statistiska centralbyråns lantbruksregister. ${ }^{373}$ Både 1971 och 1991 genomfördes så kallade lantbruksräkningar, vilket medför att uppgifterna för dessa år blev särskilt omfattande.

För att täcka in hela perioden måste således flera källmaterial kombineras. Genomförandet kräver dessutom metodologiska riktlinjer för att möjliggöra två identifikationer: Vilka hushåll bör räknas till de jordbrukande, och hur ska syskonhushåll urskiljas i källmaterialet? 


\section{Att klassificera jordbrukarhushåll}

En undersökning som spänner över drygt hundra år då Sverige gick från att i huvudsak vara ett jordbrukarland till att jordbruket spelade en undanskymd roll innebär en hel del svårigheter med att fastställa indelningsgrunder som fungerar över hela perioden. I slutet av 1800-talet fanns inga fastighetsbeteckningar och inget jordregister och det är närmast omöjligt att fastställa arealuppgifter för enskilda brukningsenheter. Fastigheter identifierades ännu i huvudsak via mantalet och deras bärkraftighet uttrycktes i ett mantalsbråk. ${ }^{374}$ Trots att mantalet förlorade sin betydelse som mått på den stående jordskatten under 1900-talets första år återgavs mantalsbråk för varje fastighet i mantalslängderna ännu $1945 .{ }^{375}$ De två sista nedslagsåren upptar mantalslängderna dock enbart fastighetsbeteckningen, vilket speglar utvecklingen av ett modernt fastighetsregister byggt på areella mått.

Källmaterialet ändrar således karaktär över tid, vilket medför att jordbrukarhushåll måste identifieras på olika sätt vid nedslagsåren. För åren 1971 och 1991 har Statistiska centralbyråns lantbruksregister, som utgår från aktiva jordbruk med en areal större än två hektar, använts för att identifiera aktiva jordbruk. Underlaget till folkräkningen 1945 innehåller arealuppgifter och med dem har det varit möjligt att identifiera jordbruk med minst två hektar åker för detta år. För de fyra tidigare nedslagsåren har emellertid inga arealuppgifter kunnat anskaffas och den avgörande indelningen har istället varit yrkesbeteckningar i folkräkningsmaterialet. Om hushållsföreståndaren titulerades som hemmansägare, jordägare, bonde, (lant)brukare eller arrendator har enheten klassats som ett jordbrukarhushåll. Jordarbetarhushåll, där yrkesbeteckningen antytt att hushållet inte var självständiga jordbrukare, har jag däremot inte tagit med. För att säkerställa att yrkesbeteckningarna inte ger en snedvriden bild av jordbruksstrukturen har en kontroll gjorts mot mantalslängderna i osäkra fall.

Vid arbetet med att identifiera jordbruken har problemen väsentligen varit två. Det första var hushåll som saknade eller hade en tvetydig yrkesbeteckning. Paradexemplet är hushåll som föreståtts 
av änkor, där kvinnan främst betecknats med sitt civilstånd men ibland med ett yrkesliknande förled, som hemmansägaränka eller bondänka. I de flesta sådana fall förestod hon gården och kan sålunda klassas som jordbrukare. Det finns emellertid fall där gården efter makens död gått familjen ur händerna men kvinnan i folkräkningarna fortsatt att betecknas som hemmansägaränka. I dessa fall var en kontroll mot mantalslängderna nödvändig för att klarlägga hushållets status. Det andra problemet rörde avgränsningen av bondegruppen nedåt. Det är förhållandevis enkelt att urskilja de något större bondehushållen och de hushåll som bestod av obesuttna (torpare, statare och liknande) eller över huvud taget inte var en del av den agrara befolkningen. Mellan dem finns det emellertid en gråzon av mer eller mindre semiagrara grupper: från olika former av småbrukare till hushåll som kombinerat en jordlott med andra yrken. En del hushåll har i folkräkningsmaterialet tilldelats hantverkstitlar som snickare eller slaktare men vid en kontroll mot mantalslängderna visat sig ha ägt och brukat en bit jord. Andra hushåll har betecknats som jordbrukare men mantalslängderna har visat att deras jordlott visserligen var mantalssatt men jämväl tämligen oansenlig, vilket gör det troligt att de hade andra inkomster vid sidan om jordbruket. Skillnaden mellan dessa två kategorier är minst sagt oklar och speglar snarast en mångsysslande grupp med ena foten i jordbruket och den andra i en ofta angränsande näring. ${ }^{376}$ Inom ramen för denna undersökning har det dock inte funnits utrymme att detaljstudera varje enskilt fall och i allmänhet har folkräkningarnas yrkesbeteckningar fătt avgöra vad som var ett jordbrukarhushåll.

\section{Vad var ett syskonjordbruk?}

Den definition av syskonjordbruk som stipulerades i första kapitlet syskon som bor och driver jordbruk ihop - har varit fullt tillräcklig i de tidigare kapitlen och med tanke på källmaterialets karaktär hade en skarpare definition varken gjort från eller till. I det här kapitlet flyttar analysen ner på hushållsnivå, vilket gör det nödvändigt att kunna skilja syskonjordbruk från andra hushåll. Boendemönstret 
är grundstommen i begreppet och kommer vara det överordnade kriteriet även i detta kapitel, men huruvida syskonen ägde allting på lika villkor eller ett eller flera av dem fick en annan position än på grund av sitt jordinnehav är en viktig fråga som jag kommer att undersöka vidare i detta kapitel och nästa. Det finns dock skäl att fördjupa definitionen. Att syskonen bodde tillsammans på gården är ett nödvändigt men inte tillräckligt kriterium. Fyra andra faktorer bör också beaktas: syskonens föräldrar, åldersfördelning, civilstånd samt arbetsförhållanden.

Ett hushåll bestående av en eller två föräldrar och en skara små barn skulle uppfylla boendekriteriet men utgör knappast ett syskonjordbruk. För att definitionen ska avspegla det kan man låta föräldrarnas status vara avgörande: om föräldrarna (föräldern) fortfarande förestår jordbruket skulle det inte räknas som ett syskonhushåll. Då uppstår emellertid ett annat problem: det tycks inte ha varit helt ovanligt att föräldrarna (föräldern) behöll kontrollen över jordinnehavet långt upp i åren eller rentav livet ut, samtidigt som det $\mathrm{i}$ hushållet fanns vuxna hemmavarande barn. I praktiken kan det praktiska ansvaret ha övergått till nästa generation, medan det formella innehavet och ägartiteln stannade hos den äldre. ${ }^{377}$ Det är en avsevärd skillnad mellan en gård som förestås av en förälder med fem barn i tioårsåldern eller strax därunder och samma gård 30 år senare där samma personer bor kvar. I kapitel 1 kritiserade jag Hammel och Lasletts typologi för olika hushåll just för att det saknade ett sådant åldersperspektiv. ${ }^{378} \mathrm{Om}$ barnen stannar kvar på gården år efter år passeras så småningom en punkt där familjekaraktären förändras. Till boendemönstret bör således läggas ett ålderskriterium.

Att dra en skarp åldersgräns är emellertid en grannlaga uppgift. I analyser av olika hushållstyper är utgångspunkten ofta en händelse som radikalt omformar hushållets sammansättning, som att föräldrarna dör eller att barnen flyttar ut eller gifter sig. ${ }^{379}$ Kännetecknande för många syskonjordbruk är dock snarast bristen på sådana händelser. Att syskon bor kvar tillsammans i föräldrahemmet kan ses som en icke-händelse i förhållande till det förväntade: upplösningen av den rumsliga familjegemenskapen. Beslutet att 
flytta kanske växer fram under lång tid, men själva flytten kan tidsbestämmas. Att inte flytta kan också ses som ett - mer eller mindre medvetet - beslut, men det är svårare att tidsbestämma. När i tid uteblir händelsen? Att en tolvåring inte har lämnat hemmet är inte uppseendeväckande, att flera fyrtioåringar bor kvar är det. När är det rimligt att förvänta sig att de vuxna barnen flyttade ut? I en undersökning av flyttningsmönster i 1800 -talets agrarsamhälle spårar ekonomhistorikern Martin Dribe en tendens att barn till bönder lämnade föräldrahemmet allt senare. Några riktigt sena avflyttningar var det dock inte tal om - de barn som alls lämnade hemmet gjorde det nästan alltid före 30 års ålder. ${ }^{380}$ Även om det är möjligt att åldern vid utflyttning ökade ytterligare något under de följande decennierna kan Dribes resultat användas för att avgöra när icke-händelsen att stanna istället för att flytta inträffade. För att ge viss marginal för att uppbrottet från familjen kunde komma ytterligare något år senare under 1900-talet används 35 år som åldersgräns. En familj med någon förälder och minst två hemmavarande barn över 34 år har jag således räknat som syskonenhet, även om föräldern i källmaterialet fortsatt markerats som innehavare av jordbruket. Ett undantag är de familjer där någon hade ett påtagligt mentalt eller fysiskt handikapp: om två syskon bodde på en gård tillsammans och det ena betecknades som "idiot" eller "sinnesslö" är det knappast rimligt att räkna det som ett syskonjordbruk. ${ }^{381}$ Sådana hushåll har jag uteslutit såvida det inte fanns ytterligare syskon i hushållet.

I kapitel 3 framgick att syskons samboende ofta gick hand i hand med att de var ogifta. I det följande har jag emellertid inte låtit civilstånd vara ett avgörande kriterium för huruvida ett hushåll var ett syskonjordbruk. Ett skäl är att hushåll med både ogifta och gifta syskon är minst lika intressanta att studera som de där ingen var gift. Istället kommer äktenskapets roll att vara en av de viktigaste frågorna i det här kapitlet. Det motiveras ytterligare av att äktenskapsförhållanden inte sällan har skymt syskonrelationernas betydelse inom familjehistorisk forskning; har det funnits ett äktenskap i hushållet har det uppfattats som normerande och hierarkiskt placerats först. ${ }^{382}$ Genom att låta äktenskapsfrågan bli 
en del av undersökningen istället för att lägga in den i definitionen blir det därmed möjligt att ta analysen ett steg längre.

Arbetsförhållandena på gården skulle kunna vara en färde aspekt av definitionen. I normalfallet torde de samboende syskonen i huvudsak ha arbetat på gården, även om det också går att tänka sig att de enbart delade boende, exempelvis att någon ensam hade hand om jordbruket medan övriga arbetade utanför hemmet. Det finns dock inget källmaterial som gör det möjligt att mer ingående analysera syskonens eventuella förvärvsarbete, och dessutom är det svårt att dra en skarp gräns mellan arbete på gården och på annat håll. På många gårdar upptog säkerligen jordbruksarbete på den egna gården all arbetstid, medan det på andra förekom att ett eller flera syskon tidvis arbetade utanför gården, exempelvis med säsongsarbete i skogen. En sådan kombination av arbete på den egna gården och biinkomster kännetecknade stora delar av småbrukarhushållen i Sverige under 1900-talets första hälft och var därmed inte något säreget för syskonhushåll. ${ }^{383}$ Arbetsförhållandena kommer att diskuteras i nästa kapitel, men för denna delstudie har det inte varit något avgörande kriterium för syskonenheter.

Sammanfattningsvis definierar jag i detta kapitel syskonjordbruk som ett jordbrukarhushåll där två eller flera vuxna syskon bor tillsammans och där minst ett av dem är ansvarig för gården eller där minst två barn i åldern 35 år och uppåt bor hemma samtidigt som föräldragenerationen ännu har det formella ansvaret för gården. Det kan tilläggas att definitionen sammanfaller med den bredare bestämning av syskonhushåll (frérèche) som återfinns i Hammel och Lasletts hushållstypologi, med tillägg av ett ålderskriterium. ${ }^{384}$

\section{Tio socknar}

För att kunna studera hur vanligt förekommande syskonjordbruk var på skilda orter har tio socknar från olika delar av landet valts ut. Vid urvalet eftersträvades en blandad sammansättning ifråga om både geografiskt läge och jordbrukets förutsättningar, samt att jordbruk skulle vara traktens dominerande näring. Av arbetsekonomiska skäl valde jag bort socknar med väldigt många jordbruk. ${ }^{385}$ Valet föll 


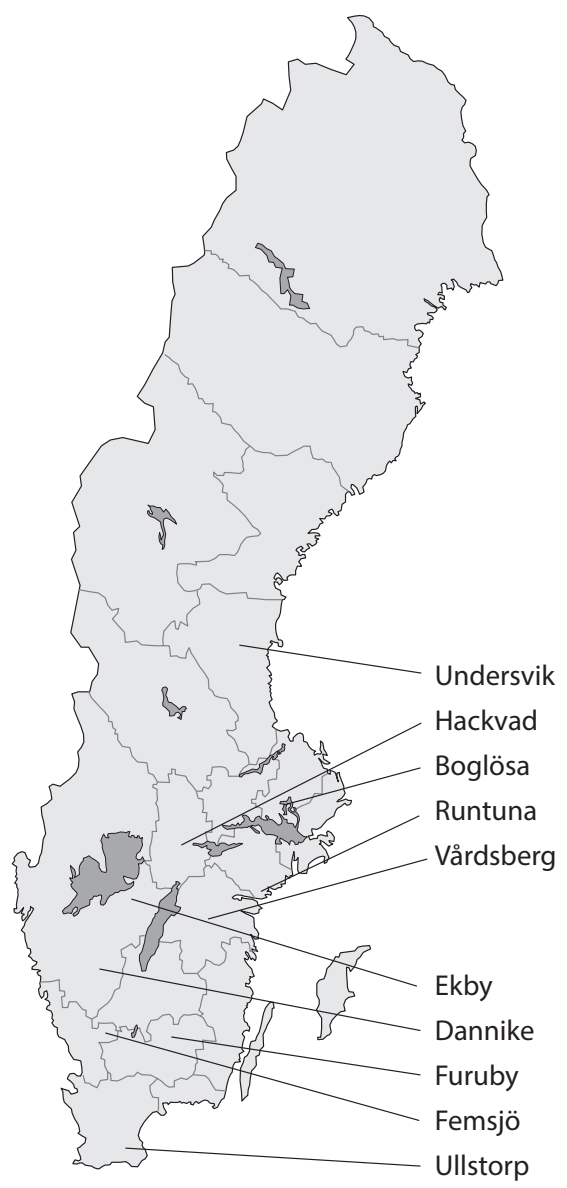

De tio undersökningsområdena.

slutligen på Undersvik (Gävleborgs län), Hackvad (Örebro), Boglösa (Uppsala), Runtuna (Södermanland), Vårdsberg (Östergötland), Ekby (Skaraborg), Dannike (Älvsborg), Femsjö (Jönköping, sedan 1974 Halland), Furuby (Kronoberg) samt Ullstorp (Kristianstad).

De undersökta socknarna är inte ovanliga i förhållande till sin omgivning, men den primära avsikten med urvalet är inte att göra en jämförelse av socknar från olika regioner. En sådan försvåras inte minst av skillnader i jordbruksstruktur. Av de tio socknarna kännetecknades fem (Boglösa, Runtuna, Vårdsberg, Hackvad och Ekby) av relativt stora gårdar. I 1944 års jordbruksräkning 


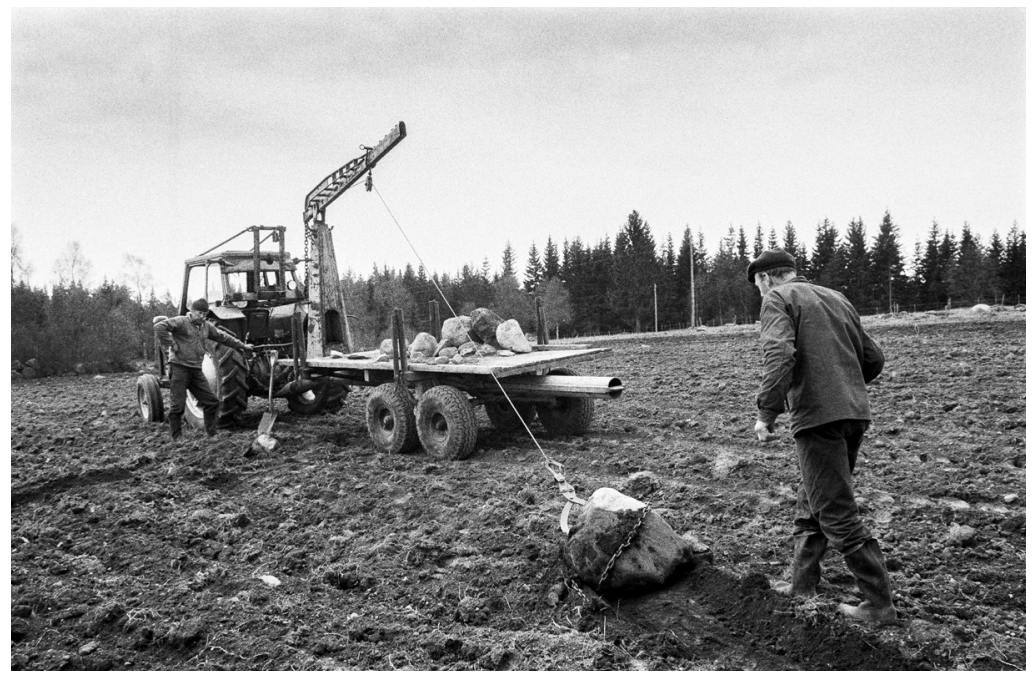

Fotografen Sune Jonsson dokumenterade i början av 1970-talet vardagen bland småbrukarna i småländska Furuby under ett år. Den stenbrutna småländska jorden bjöd på hårt arbete, även om maskiner gjort det lättare. Stenröjning hos Bengt på Söragårn. Foto: Sune Jonsson/Västerbottens museum.

omfattade de flesta enheter i dessa socknar runt eller över tio hektar åker, och med undantag för västgötska Ekby kan de grovt räknas till Östsverige. ${ }^{386}$ De övriga fem sockarna utmärktes av att gårdarna var något mindre; 1944 omfattade de vanligen mellan två och tio hektar åker. ${ }^{387}$ De tre mest utpräglade småbrukarsocknarna var småländska Femsjö och Furuby samt västgötska Dannike, vilka kan räknas till Västsverige. I grunden speglar detta en skillnad mellan Väst- och Östsverige - gårdarna var generellt större i öst - men det gör det också svårt att peka på någon form av kulturell olikhet skild från jordbruksstrukturen. ${ }^{388}$ Även om en kortare jämförelse ändå görs längre fram i kapitlet är utgångspunkten med andra ord inte att framställa en bild av starka regionala kulturskillnader. I sin studie av familjejordbruk i Sverige under 1900-talet intar Iréne Flygare en liknande position: trots att hon studerar ett västsvenskt och ett östsvenskt område understryker hon likheterna på gårdsnivå och låter social tillhörighet väga tyngre än regional. ${ }^{389}$ 
Tabell 4.1. Antal jordbruksenheter i tio socknar enligt officiell statistik.

\begin{tabular}{|c|c|c|c|c|c|}
\hline & 1927 & 1944 & 1944 & 1971 & 1991 \\
\hline & $>1 / 4$ ha & $>1 / 4$ ha & $>2$ ha & $>2$ ha & $>2$ ha \\
\hline Boglösa & 81 & 74 & 66 & 42 & 36 \\
\hline Runtuna & 92 & 94 & 78 & 38 & 38 \\
\hline Vårdsberg & 94 & 88 & 68 & 39 & 26 \\
\hline Femsjö & 103 & 92 & 78 & 44 & 23 \\
\hline Furuby & 125 & 119 & 91 & 44 & 25 \\
\hline Ullstorp & 90 & 80 & 69 & 42 & 23 \\
\hline Dannike & 97 & 89 & 64 & 24 & 14 \\
\hline Ekby & 75 & 69 & 60 & 36 & 30 \\
\hline Hackvad & 83 & 77 & 57 & 39 & 35 \\
\hline Undersvik & 129 & 151 & 101 & 46 & 27 \\
\hline Totalt & 969 & 928 & 732 & 394 & 277 \\
\hline
\end{tabular}

Källa: Jordbruksräkningen 1927 och 1944, Lantbruksräkningen 1971, uppgifter från Lantbruksregistret 1991.

I tabell 4.1 framgår antalet jordbruksenheter inom respektive socken vid fyra tillfällen under 1900-talet. Den tidiga jordbruksstatistiken ger inte möjlighet att storleksindela jordbruken och i 1927 års Jordbruksräkning ingår alla brukningsenheter från 0,25 hektar åker och uppåt utan åtskillnad. Vid lantbruksräkningen 1971 och i lantbruksregistret 1991 sattes den nedre gränsen istället vid två hektar. För att kunna göra jämförelser har siffrorna från 1944 års jordbruksräkning i tabellen delats upp i två kolumner, där den första avser enheter från 0,25 hektar (vilket således är jämförbart med 1927 års uppgifter) och den andra avser enheter från två hektar (jämförbart med de två senare nedslagsåren). Den totala skillnaden mellan 1927 och 1944 var mycket liten, men bakom detta döljer sig tre skilda mönster. Två socknar uppvisade särdrag: Runtuna, där antalet jordbruk närmast var konstant, och Undersvik, där antalet ökade kraftigt. ${ }^{390}$ I de övriga åtta minskade antalet enheter något, totalt motsvarande knappt tio procent. Det var dock bara en liten föraning om den totala omvandling av jordbruksstrukturen som tog fart efter 1945. Enbart på de brukningsenheter som översteg två hektar minskade antalet jordbrukare i de tio socknarna mellan 1944 och 1991 med 62 procent, och i Sverige som helhet med närmare 
67 procent. ${ }^{391}$ På ett knappt halvsekel försvann således två av tre jordbrukare. ${ }^{392}$ Skillnaden mellan olika områden var emellertid stor. I Hackvad stannade tillbakagången vid knappa 40 procent, medan den i Dannike uppgick till det dubbla. Som väntat drabbades områden med en större andel små gårdar betydligt hårdare av nedläggningsvågen; det var ju syftet med den jordbrukspolitik som fördes från 1940-talets slut. I de fem socknar som kännetecknades av en majoritet gårdar med mindre än tio hektar åker försvann mellan 67 och 78 procent av alla gårdar. Motsvarande tal i de fem socknarna med större gårdar låg istället mellan 39 och 51 procent.

Den officiella statistiken ger en viktig bakgrundsbild av undersökningsområdena och den generella utvecklingen av jordbruksstrukturen. Som redan diskuterats bygger emellertid arbetsmetoden i detta kapitel främst på yrkesbeteckningar i folkräkningarna och det är därför av intresse hur antalet jordbrukarhushåll förändrades över tid.

Tabell 4.2. Antal jordbrukarhushåll i tio socknar, 1870-1991.

$\begin{array}{lccccccc} & \mathbf{1 8 7 0} & \mathbf{1 8 9 0} & \mathbf{1 9 1 0} & \mathbf{1 9 3 0} & \mathbf{1 9 4 5} & \mathbf{1 9 7 1} & \mathbf{1 9 9 1} \\ \text { Beräknat } & 631 & 651 & 626 & 667 & 700 & 394 & 277 \\ \text { Statistiska } & - & - & - & - & 732^{\mathrm{a}} & 394 & 277 \\ \text { uppgifter } & & & & & & & \end{array}$

Källa: församlingsbokutdrag (1870, 1890, 1910, 1930 och 1945), mantalslängder (samtliga nedslagsår) och uppgifter ur husförhörslängder och församlingsböcker (RA), samt Jordbruksräkningen 1944 och Lantbruksregistrets primäruppgifter för 1971 och 1991 (SCB), för Boglösa, Runtuna, Vårdsberg, Femsjö, Furuby, Ullstorp, Dannike, Ekby, Hackvad och Undersvik. Statistiska uppgifter för 1945 från Jordbruksräkningen 1944, tabell 1.

$\mathrm{a}=$ uppgiften avser 1944 .

Sett över alla sju nedslagsår omfattar undersökningen närmare 4000 observationer av enskilda jordbrukarhushåll. Av tabell 4.2 ovan framgår att för de två sista nedslagsåren är antalet jordbruk identiskt med jordbruksstatistiken. Den enkla anledningen är att det är just den statistiska förteckningen som legat till grund för identifikationen av jordbruken. Den lilla skillnaden för 1945 beror sannolikt främst på att uppgifterna avser två olika år: folkräkningen avsåg 1945 och jordbruksräkningen $1944 \cdot{ }^{393}$ De tre första nedslagsåren låg antalet jordbruk runt 650, för att därefter stiga till 700 fram till 1945. Det 
är dock svårt att säga om detta speglar någon verklig ökning eller enbart är en effekt av att identifieringen av jordbrukarhushållen de första nedslagsåren byggde på yrkesbeteckningar och från 1945 på åkerareal. Att det finns en sådan effekt är troligt. Det fanns 1945 gott om jordbruk som omfattade minst två hektar jord men där ägaren betecknades som exempelvis snickare, montör, vägarbetare eller skogsarbetare.

\section{Syskonjordbrukens omfattning}

Den viktigaste frågan att inledningsvis få klarhet i är hur många syskonenheterna var. I tabell 4.3 framgår hur många av jordbrukarhushållen i de tio socknarna som enligt den fastställda definitionen var syskonjordbruk samt vilken andel de motsvarade vid respektive nedslagsår.

Tabell 4.3. Antal jordbrukarhushåll och syskonjordbruk i tio socknar, 1870-1991.

$\begin{array}{lrrrrrrr} & \mathbf{1 8 7 0} & \mathbf{1 8 9 0} & \mathbf{1 9 1 0} & \mathbf{1 9 3 0} & \mathbf{1 9 4 5} & \mathbf{1 9 7 1} & \mathbf{1 9 9 1} \\ \text { Antal jordbrukarhushåll } & 631 & 651 & 626 & 667 & 700 & 394 & 277 \\ \text { Syskonjordbruk, antal } & 7 & 28 & 54 & 106 & 93 & 42 & 16 \\ \text { Syskonjordbruk, andel } & 1 & 4 & 9 & 16 & 13 & 11 & 6\end{array}$

Källa: Se källangivelser under tabell 4.2.

Det är tydligt att både antalet och andelen syskonjordbruk förändrades kraftigt över tid. Vid det första undersökningsåret 1870 var det ett nära nog okänt fenomen: sju av drygt 600 undersökta hushåll uppfyllde då kriterierna, vilket motsvarade ungefär en procent. Under de följande decennierna ökade andelen stadigt. Redan 1890 fanns fyra gånger så många syskonhushåll, 28 stycken. Därefter fördubblades andelen fram till 1910 och ytterligare en gång fram till 1930, då inte mindre än 16 procent av jordbrukarhushållen i de undersökta socknarna var syskonjordbruk. Därefter bröts trenden och andelen minskade något till 1945 och ytterligare till 1971 . Någon omedelbar avveckling var det dock inte fråga om - trots att nästan 40 procent av jordbruken lades ner fram till 1971 utgjorde syskonjordbruken fortsatt runt 11 procent. Först under perioden fram till 1991 går det att tala om en långsam upplösning. ${ }^{394}$ 
Med utgångspunkt i ovanstående siffror är det möjligt att göra en grov periodisering av syskonjordbruk som företeelse. Som framgått av tidigare forskning tycks de ha varit så gott som okända under den förra delen av 1800-talet och resultaten från nedslaget 1870 stödjer i allt väsentligt denna bild. Vidare bekräftas den indikation på en förändring mot slutet av 1800-talet som några forskare funnit. Erik Hallberg uppskattade att ungefär 13 procent av jordbruken i ett område i Dalsland var syskonjordbruk runt 1930, en siffra som stämmer väl överens med den utveckling som tecknats här. ${ }^{395} \mathrm{I}$ de tio undersökta socknarna ökade företeelsen i omfång under ett halvt sekel, från cirka 1880 till cirka 1930. Huvudresultatet i förra kapitlet - en ökande förekomst av långvariga gemensamhetsbruk under 1900-talets första decennier - stämmer väl överens med den tilltagande andelen syskonhushåll i de undersökta områdena. Det var under 1900-talets första decennier som ökningen var som kraftigast. Kulmen förefaller ha nåtts på 1930-talet, då nästan var sjätte jordbruksenhet i de undersökta socknarna var ett syskonjordbruk. Även efter att toppnoteringen passerats utgjorde de ett betydande inslag på landsbygden. Trots att jordbruksstrukturen på några decennier förändrades i grunden när gårdar lades ner eller slogs samman låg andelen syskonjordbruk stabilt en bit över 10 procent. Bortsett från toppnoteringen 1930 kan en relativt långvarig stabil fas identifieras: från 1910 och åtminstone 60 år framåt utgjorde syskonhushållen runt eller strax över 10 procent av jordbruken. Någon gång på 1970-talet inträdde en stagnationsperiod, vilken sannolikt har fortgått även efter 1991, då andelen låg på knappt 6 procent. Fyra faser kan således urskiljas: en förperiod fram till cirka 1870 med i princip inga syskonjordbruk, en tillväxtperiod från cirka 1870 till cirka 1930, en stabil period fram till 1970-talet och en stagnationsperiod under seklets sista decennier.

\section{Generella mönster och lokala avvikelser}

Den givna karaktäristiken avser det sammanvägda resultatet av alla undersökta socknar. Var då utvecklingen likartad i de tio socknarna? Att flytta ner analysen på sockennivå är inte okomplicerat. 
Eftersom det i de flesta av socknarna som mest fanns mellan 50 och 80 jordbruk och antalet dessutom sjönk över tid väger varje enskild observation tungt. Att ett syskonjordbruk upplöstes eller tillkom kan påverka andelen med flera procentenheter. Det är ett argument för att det sammanvägda resultatet är mer tillförlitligt, men det gör det också väsentligt att undersöka om det generella mönstret döljer stora lokala variationer. Om samma utvecklingstendenser går att finna i de flesta områden styrks periodiseringen, men om de ingående områdena tvärtom präglades av disparata mönster blir bilden mer komplicerad. I tabell 4.4 återges andelen syskonenheter i varje socken vid de sju undersökningsåren.

Tabell 4.4. Andel syskonjordbruk i tio socknar, 1870-1991.

$\begin{array}{lccrrrrr} & \mathbf{1 8 7 0} & \mathbf{1 8 9 0} & \mathbf{1 9 1 0} & \mathbf{1 9 3 0} & \mathbf{1 9 4 5} & \mathbf{1 9 7 1} & \mathbf{1 9 9 1} \\ \text { Boglösa } & 0 & 8 & \mathbf{1 3} & 11 & 2 & 10 & 6 \\ \text { Runtuna } & 2 & 7 & 5 & 6 & \mathbf{8} & 5 & 5 \\ \text { Vårdsberg } & 2 & 2 & 12 & 9 & \mathbf{1 3} & 10 & 4 \\ \text { Femsjö } & 0 & 0 & 2 & \mathbf{3 6} & 33 & 27 & 13 \\ \text { Furuby } & 0 & 5 & 7 & 15 & \mathbf{1 7} & 11 & 12 \\ \text { Ullstorp } & 1 & 1 & 8 & \mathbf{8} & 7 & 0 & 0 \\ \text { Dannike } & 4 & 9 & 12 & \mathbf{2 0} & 14 & 17 & 14 \\ \text { Ekby } & 2 & 6 & 16 & 19 & \mathbf{2 1} & 11 & 0 \\ \text { Hackvad } & 2 & 4 & 16 & \mathbf{1 8} & 8 & 8 & 6 \\ \text { Undersvik } & 0 & 4 & 4 & \mathbf{1 1} & 7 & 9 & 4 \\ \text { Samtliga } & \mathbf{1} & \mathbf{4} & \mathbf{9} & \mathbf{1 6} & \mathbf{1 3} & \mathbf{1 1} & \mathbf{6}\end{array}$

Källa: Se källangivelser under tabell 4.2. Anm.: Högsta andelen för varje socken är markerad i fetstil.

Vid tvärsnittet 1870 var syskonjordbruk ovanliga i samtliga områden. I fyra socknar saknades de helt och i fem fanns bara ett. Trots variationer mellan socknarna går det att i samtliga skönja en successiv ökning fram till 1930. Toppnoteringarna nåddes i allmänhet under 1930- och 1940-talen, men magnituden varierade markant mellan områdena. I Runtuna och Ullstorp uppgick syskonjordbruken aldrig till mer än 8 procent. I fyra områden utgjorde de som mest omkring 20 procent och i småländska Femsjö 1930 närmast häpnadsväckande 36 procent. Utvecklingen i Femsjö är särpräglad på flera sätt: socknen gick från att ha den lägsta andelen syskonjordbruk vid de tre första nedslagen till att ha den högsta vid de följande. 
Det generella mönstret med en ökning fram till cirka 1930 och en successiv nedgång fram till 1991 är tydligt urskiljbart i åtta av tio socknar. Undantagen är Boglösa, som nådde sin toppnotering redan 1910 men där andelen sedan dalade till 1945 innan den åter kravlade sig upp till tvåsiffrigt 1971, och Runtuna, där andelen inte förändrades särskilt mycket över tid men heller aldrig blev särskilt hög.

\section{Smått och stort, öst och väst}

I presentationen av de tio områdena påpekades att de grovt kan delas in i fem med större gårdar och fem med mindre. I tabell 4.5 redovisas dessa två grupper var för sig.

Tabell 4.5 Andel syskonjordbruk i fem socknar med större gårdar och fem med små, 1870-1991.

$\begin{array}{lccccccc} & \mathbf{1 8 7 0} & \mathbf{1 8 9 0} & \mathbf{1 9 1 0} & \mathbf{1 9 3 0} & \mathbf{1 9 4 5} & \mathbf{1 9 7 1} & \mathbf{1 9 9 1} \\ \text { Stora } & 1 & 6 & 12 & 13 & 10 & 9 & 4 \\ \text { Små } & 1 & 3 & 6 & 19 & 16 & 13 & 8 \\ \text { Samtliga } & \mathbf{1} & \mathbf{4} & \mathbf{9} & \mathbf{1 6} & \mathbf{1 3} & \mathbf{1 1} & \mathbf{6}\end{array}$

Källa: Se källangivelser under tabell 4.2.

Som framgår inträffade runt 1930 ett påtagligt skifte i utvecklingen. Från 1870 ökade andelen syskonjordbruk i de båda områdestyperna, men socknarna med större gårdar hade en betydligt större andel både 1890 och 1910. Fram till 1930 blev dock syskonhushåll betydligt vanligare i småbrukarsocknarna. Givetvis spelar den explosionsartade utvecklingen i Femsjö en nyckelroll för scenförändringen, men även om man räknar bort Femsjö var syskongårdarna 1930 vanligare i småbrukarsocknarna än i de fem med större gårdar. ${ }^{396}$ Detta mönster höll i sig genom både den stabila fasen efter 1930 och avvecklingsfasen mot seklets slut. Det förefaller som att syskonjordbruk inte självklart kan sägas utmärka vare sig de små eller stora jordbruken, eller snarare att företeelsen skiftade karaktär med tiden. Det är emellertid viktigt att hålla i minnet att inget område var homogent; småbrukarbygderna innehöll även enstaka större gårdar och omvänt. Längre fram i kapitlet för jag ner analysen på gårdsnivå med hjälp av en indelning av jordbruken i olika storleksklasser. 


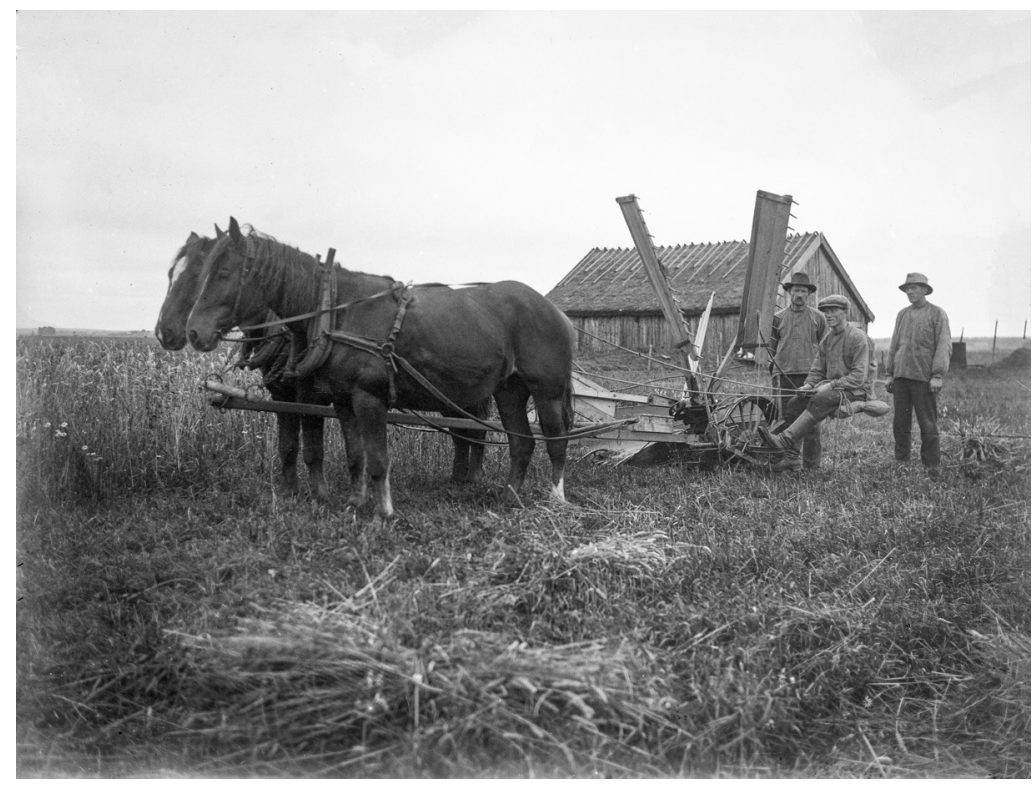

Skörd med självbindare i Ekby socken, 1928. Foto: Valdemar Walldén/Västergötlands museum.

Uppdelningen i socknar med små respektive stora gårdar följer i stor utsträckning en indelning i Öst- och Västsverige. Det kan dock vara intressant att ställa ett renodlat öst/väst-mönster i relation till uppdelningen i små och stora socknar. I tabell 4.6 har därför de fyra socknarna Boglösa, Vårdsberg, Hackvad och Runtuna räknats som östsvenska och Ekby, Dannike, Furuby och Femsjö som västsvenska. Skånska Ullstorp och norrländska Undersvik har helt undantagits från jämförelsen. Samma skifte i mönstret framträder runt 1930, men proportionerna är något annorlunda. Å ena sidan är skillnaderna vid nedslagsåren 1890 och 1910, då syskonjordbruken var något vanligare i Östsverige, mindre. Från 1930, då de blev vanligare i Västsverige, är å andra sidan skillnaden mellan öst och väst betydligt större. Den stora ökningen mellan 1910 och 1930, då andelen syskonjordbruk närmast fördubblades, förefaller ha varit ett västsvenskt fenomen. Utvecklingen i Femsjö har stor inverkan på siffrorna, men räknas socknen bort hade ändå de västsvenska områdena en klart högre andel 1930. 
Tabell 4.6 Andel syskonjordbruk i fyra östsvenska och fyra västsvenska socknar, 1870-1991.

$\begin{array}{lccccccc} & \mathbf{1 8 7 0} & \mathbf{1 8 9 0} & \mathbf{1 9 1 0} & \mathbf{1 9 3 0} & \mathbf{1 9 4 5} & \mathbf{1 9 7 1} & \mathbf{1 9 9 1} \\ \text { Öst } & 1 & 5 & 11 & 11 & 8 & 8 & 5 \\ \text { Väst } & 1 & 4 & 8 & 23 & 22 & 17 & 9 \\ \text { Samtliga } & 1 & 4 & 9 & 16 & 13 & 11 & 6\end{array}$

Källa: Se källangivelser under tabell 4.2.

Det kan noteras att detta mönster inte alls stämmer överens med resultaten i kapitel 3. De nationella enkäterna pekade snarast på att Västsverige utmärktes av långvariga gemensamhetsbruk i början av 1900-talet men att skillnaderna mellan olika regioner blev mindre med tiden. Diskrepansen mellan dessa två resultat är inte helt enkel att förklara. Det är möjligt att de fyra socknarna från det västsvenska området som har undersökts inte överensstämmer med det allmänna mönstret i regionen, men eftersom utvecklingen i de fyra inte skiljer sig mycket från varandra är det mindre troligt. Det är mer sannolikt att skillnaden kommer sig av att de västsvenska socknarna som analyserats i stor utsträckning är småbrukarsocknar. Som framgick i tabell 4.4 ökade andelen syskonenheter först i områden med något större gårdar, och den enda västsvenska socknen inom denna grupp, Ekby, uppvisade faktiskt 1910 den högsta andelen av samtliga socknar. De flesta socknar i Västsverige var emellertid småbrukarsocknar och urvalet kan därmed inte förklara skillnaderna i resultat. Mest sannolikt är därför att den försiktiga slutsatsen i kapitel 3, att Västsverige tidigt utmärktes av en högre andel syskonjordbruk, är felaktig. Den bild som enkätsvaren gav 1907 tycks ha överskattat Västsveriges utveckling mot ett flerarvingesystem. Samtidigt verkar de senare enkäterna närmast ha underskattat den. Under syskonjordbrukets verkliga glansdagar var andelen påtagligt högre i Västsverige. Det visar sig i toppnoteringarna i tabell 4.4: av de fem socknarna med högst uppmätt andel syskonhushåll var fyra västsvenska. Det tycks således finnas fog för att påstå att syskonjordbruk var något vanligare i Västsverige från 1930-talet och framåt. Det rör sig dock inte om en skarp kulturgräns utan snarare en gradskillnad. 


\section{Varaktighet och upplösning}

Syskonjordbruken blev under 1900-talet relativt vanliga i de tio socknarna, men hur många fall rör det sig om? Var det samma individer som i brist på arvingar satt på sina gårdar decennierna igenom, eller var tillströmningen av nya syskonjordbrukare ständigt hög? Totalt finns 259 syskongrupper som vid minst ett nedslagstillfälle klassificerats som ett syskonjordbruk. I tabell 4.7 nedan har dessa delats in efter när de förekommer första gången.

Tabell 4.7. Första förekomst för 259 syskonjordbruk, tio socknar 1870-1991.

$\begin{array}{lccccccc} & \mathbf{1 8 7 0} & \mathbf{1 8 9 0} & \mathbf{1 9 1 0} & \mathbf{1 9 3 0} & \mathbf{1 9 4 5} & \mathbf{1 9 7 1} & \mathbf{1 9 9 1} \\ \text { Antal syskonjordbruk } & 7 & 28 & 54 & 106 & 93 & 42 & 16 \\ \text { Första förekomst } & 7 & 25 & 46 & 96 & 49 & 29 & 7 \\ \text { Andel första förekomst } & 100 & 89 & 85 & 91 & 53 & 69 & 44\end{array}$

Källa: Se källangivelser under tabell 4.2.

Det mest slående resultatet är den stora andelen nya syskonjordbruk vid varje undersökningsår. När antalet ökade mellan 1890, 1910 och 1930 var det i mycket hög grad fråga om att nya syskongrupper tillkom. Bara runt var tionde syskonjordbruk förekom vid två nedslagstillfällen. Till stor del är detta en effekt av att syskongårdar var i stark tillväxt under denna tid. I och med att antalet fördubblades mellan 1890 och 1910 och ånyo mellan 1910 och 1930, är det givet att minst 50 procent förekom för första gången. I samband med att den mer stabila fasen inträdde från 1945 minskade omsättningen betydligt. Av 1945 års syskonjordbruk hade nästan hälften förekommit 1930 och även vid de två sista nedslagsåren var andelen nytillkomna klart lägre. Det kortare intervallet mellan 1930 och 1945 spelar sannolikt en viss roll och på liknande sätt torde den långa perioden fram till 1971 delvis förklara att många nya uppstått. Fram till 1991 minskade andelen nya syskonenheter mycket kraftigt och mer än hälften av 1991 års syskonjordbrukare förekom redan 1971. Mycket tyder därmed på en slutlig avveckling av syskonjordbruket som företeelse vid seklets slut.

Sett över hela undersökningsperioden förekom 78 syskonenheter 
mer än en gång, vilket motsvarar 30 procent av samtliga. Även om den höga omsättningen i början av 1900-talet kan förklaras av den stora tillväxten måste slutsatsen bli att syskonjordbruken inte var påfallande långvariga. En viktig förklaring ligger sannolikt $\mathrm{i}$ definitionen. För att räknas som syskonjordbruk måste syskonen ha varit relativt gamla redan första gången de noterades, och med tjugoårsintervall mellan jämförelserna är det naturligt att många föll ifrån under tiden. Samtidigt öppnar resultatet upp för en mer kritisk fråga om undersökningens validitet. Var det i själva verket så att många hushåll passerade igenom en fas som syskonjordbruk innan den ursprungliga familjekonstellationen slutligt splittrades och en arvinge ensam övertog gården? Visar resultaten verkligen uppkomsten av beständiga strukturer, eller snarare en förändring mot att syskonen bröt upp först efter 35-årsdagen?

För att bringa klarhet i frågan har jag undersökt de 243 enheter som någon gång före 1991 upphörde att vara syskonjordbruk för att utröna varför de försvann. ${ }^{397}$ Orsakerna har sammanförts till fem kategorier. Med dödsfall avses att samtliga eller åtminstone alla utom ett syskon avlidit, varmed statusen som syskonenhet tilländalöpt. Med flytt avses att samtliga syskon flyttat från gården; har däremot en arvinge stannat kvar och ensam övertagit gården har det klassats som övergång till en. Om syskonen lever och bor kvar men inte längre brukar gården har det betecknats som jordbruk upphört. Dessutom finns en handfull övriga fall som inte passar i någon annan kategori. Resultatet framgår av tabell 4.8.

Tabell 4.8. Syskonjordbruk efter anledning till upphörande, tio socknar 1870-1991.

\begin{tabular}{|c|c|c|c|c|c|c|c|}
\hline & 1890 & 1910 & 1930 & 1945 & 1971 & 1991 & $\begin{array}{c}\text { Totalt antal } \\
\text { (andel) }\end{array}$ \\
\hline Upphört sedan föregående & 4 & 20 & 44 & 63 & 79 & 33 & $243(100)$ \\
\hline Dödsfall & 2 & 7 & 20 & 21 & 49 & 15 & $114(47)$ \\
\hline Flytt & 2 & 3 & 15 & 12 & 13 & 4 & $49(20)$ \\
\hline Övergång till en & - & 6 & 3 & 16 & 10 & 5 & $40(16)$ \\
\hline Jordbruk upphört & - & 2 & 5 & 11 & 7 & 7 & $32(13)$ \\
\hline Övriga & - & 2 & 1 & 3 & - & 2 & $8(3)$ \\
\hline
\end{tabular}

Källa: Se källangivelser under tabell 4.2. 
Det absolut vanligaste var att syskonjordbruket bestod till dess alla utom ett av syskonen avlidit. Nästan hälften av enheterna bestod på detta sätt fram till dess döden kom emellan. Det var den enskilt viktigaste orsaken vid alla sex nedslagstillfällena, men kännetecknar särskilt den stora grupp som upphörde mellan 1945 och 1971. Att syskonen höll ihop livet ut innebär emellertid inte att alla blev gamla. Det finns gott om exempel på att gemenskapen upplöstes på grund av att någon avled i 40- eller 50-årsåldern.

En relativt stor andel enheter upphörde på grund av att samtliga syskon flyttade ifrån gården. En hel del av dem var relativt ålderstigna vid flytten, vilket gör det sannolikt att de snarast pensionerade sig. De hade således likheter med de 32 hushåll som upphörde med jordbruket och sålde eller arrenderade ut jorden. Ibland flyttade syskonen på olika håll, men påfallande ofta anges samma uppgifter i flyttningslängderna för samtliga vilket sannolikt innebar att gemenskapen i hushållet bestod även sedan jordbruksdriften upphört.

Att samtliga syskon utom ett flyttade så att en arvinge ensam övertog gården förekom i 40 fall, vilket motsvarar drygt 16 procent. Det var särskilt vanligt mellan 1930 och 1945, vilket kan tolkas som att toppnoteringen för antalet syskonjordbruk 1930 delvis berodde på att enheter som så småningom övergick till en arvinge i analysen tolkats som syskonenheter. Det är dock en slutsats med facit i hand. Det var inte möjligt att i förväg veta vilka hushållsstrukturer som skulle bli bestående och vilka som skulle lösas upp; enheter som inom några år övergick på en arvinge skilde sig inte på något avgörande sätt från enheter där syskongemenskapen blev bestående. Huruvida syskonen själva på förhand var på det klara med hur gården skulle fördelas och hushållet gestalta sig är osäkert och säkra svar är omöjliga att få. I en del fall dröjde arvingarnas utflytt tills de kommit upp över 50 eller rentav 60 år, vilket knappast gör det rimligt att beteckna det som ett försenat uppbrott från den gamla familjeenheten.

Det kan vara läge att summera resultaten så här långt och peka på fyra övergripande slutsatser. För det första blev syskonjordbruken under en period på 1900-talet mycket vanliga. Vid nedslaget 1930, då toppnoteringen uppnåddes för flertalet områden, uppgick 
andelen till runt 20 procent eller mer i hälften av områdena. För det andra var de inte en lokal företeelse. Även om andelen varierade mellan socknarna var det inte någonstans ett okänt fenomen och deras antal var överallt större under 1900-talet första hälft än under 1800-talet. För det tredje berodde utvecklingen mer på tid än plats. Mönstret med en ökning fram till cirka 1930 går att påvisa i de allra flesta socknar, likaså en därpå följande nedgång. För det fjärde var de varaktiga och inte en övergångsfas innan en arvinge tog över. De allra flesta bestod till dess syskonen avled, flyttade eller upphörde med jordbruket.

\section{Syskonhushållets sammansättning}

Syskonhushåll förekom under hela 1900-talet, men förändrades deras sammansättning över tid? Vilka syskon bodde på gårdarna? För att besvara den frågan behöver jag skifta fokus till syskonen själva. Utgångspunkt i det följande är de 259 syskongrupper som vid minst ett nedslagsår identifierats som syskonjordbrukare. Jag kommer i huvudsak att behandla dem som en sammanhållen enhet, men för vissa jämförelser finns det anledning att dela in dem kronologiskt. Eftersom antalet syskonjordbruk varierade kraftigt över tid, nedslagsåren är många och flera grupper förekom vid mer än ett nedslagsår är det mindre givande att låta varje nedslagstillfälle utgöra en analyskategori. Istället görs en indelning av hushållen i tre kategorier baserat på vilket år de första gången förekom i materialet: 1870 till 1910 när syskonjordbruken var i tillväxt (78 grupper), under storhetsperioden på 1930- och 1940-talen (145 grupper) samt 1971 och 1991 när de började försvinna (36 grupper). Jag ägnar fem aspekter särskilt intresse: antalet syskon på gården, könsfördelningen, syskonens civilstånd, eventuellt samboende med föräldrar samt syskonens ålder.

Den naturliga första frågan är hur många syskon som bodde på de aktuella gårdarna. Var det mestadels brödrapar som Erik och Sigvard, eller var det vanligare med större konstellationer som syskonen Rundqvist i Duvemåla? I tabell 4.9 har jag delat in de 259 enheterna efter antal samboende syskon det år då jag först identifierade hushållet 
som ett syskonhushåll. ${ }^{398}$ Att två personer levde tillsammans var det absolut vanligaste och förekom på 70 procent av syskonbruken. Tre personer var också relativt vanligt och förekom på ungefär vart femte syskonbruk. Enheter med fyra, fem eller sex syskon förekom men utgjorde tillsammans inte mer än 10 procent.

Tabell 4.9. Antal samboende syskon (andel) på 259 syskonjordbruk, tio socknar 1870-1991.

$\begin{array}{lccccc}\text { Antal syskon } & \mathbf{2} & \mathbf{3} & \mathbf{4} & \mathbf{5} & \mathbf{6} \\ \text { Antal enheter } & 180(70) & 53(20) & 18(7) & 6(2) & 2(1)\end{array}$

Källa: Se källangivelser under tabell 4.2.

Två arvingar som tillsammans övertog gården var bröderna Gustaf Adolf och Johan Emil Andersson på Via Larsgården i Hackvad. Enligt 1910 års folkräkning var de två bröderna över 35 år och bodde fortfarande hemma hos sina föräldrar. I familjen fanns även en syster, som lämnat hemmet några år tidigare. Efter att föräldrarna avlidit 1915 respektive 1921 övertog de två bröderna gården tillsammans. I församlingsboken noteras att de "äga gemensamt 1/8 mtl". Så förblev det tills den yngre brodern gick bort 1929. Gustaf Adolf fortsatte därefter att bruka gården, skaffade sig senare hushållerska och bodde kvar vid både 1930 och 1945 års folkräkningar. ${ }^{399}$

En betydligt större konstellation var syskonen Törnkvist på gården Göksätter i Runtuna socken. Till gården hörde 56 hektar mark varav hela 25 hektar åker. Familjen bestod förutom föräldrarna av sju barn födda mellan 1892 och 1913. De framträder i materialet första gången i samband med folkräkningen 1930, men då brukades gården ännu av föräldrarna och bara ett barn var över 35 år, varför enheten inte uppfyllde kriterierna för att räknas som syskonjordbruk. Vid nedslaget 1945 hade fadern och en av sönerna avlidit och gården förestods av modern tillsammans med de kvarvarande barnen, tre söner och tre döttrar. Fyra av barnen bodde ogifta kvar även 1971, då modern och ytterligare en av sönerna gått bort. Ännu 1991 fanns två av syskonen kvar, då 87 och 78 år gamla. ${ }^{400}$

Exemplet med de två bröderna i Hackvad illustrerar varför många enheter enbart förekom vid ett nedslagsår. Eftersom tvåsyskonjordbruket var så dominerande räckte det i många fall att 

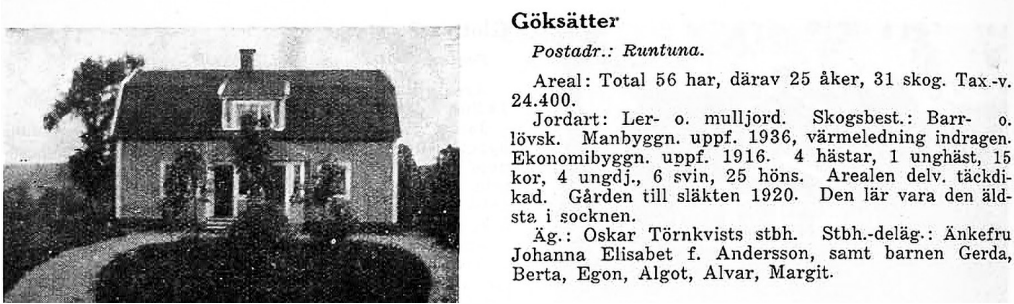

Under 1930-talet inleddes utgivningen av bokverket Gods och gårdar, som totalt kom att omfatta tusentals fastighetsbeskrivningar. Gårdarna beskrivs detaljerat vad gäller jordbruket, men uppgifterna om ägo- och boendeförhållanden är ofta knappa. Fastighetsbeskrivningen för Göksätter anger sterbhuset som ägare, men är ovanlig i det att delägarna räknas upp.

ett syskon flyttade, avled eller på annat sätt slutade att räknas till hushållet för att syskonjordbruket som företeelse skulle upphöra. När det som på Göksätter fanns fler individer från början kunde däremot syskonhushållet bestå även om något syskon föll ifrån. Det visar sig också att enheter med många arvingar var betydligt mer seglivade än tvåsyskonjordbruken. Av 26 enheter med minst fyra syskon förekom hälften vid mer än ett nedslagsår, även om det var relativt vanligt att ett eller två syskon föll ifrån mellan nedslagsåren. På enheter med tre arvingar var motsvarande andel en knapp tredjedel och bland tvåsyskonjordbruken mindre än var femte.

Fördelningen på olika stora syskongrupper visar inga påfallande variationer mellan socknarna och det finns ingen skillnad mellan socknarna med mindre och med större jordbruk. Mellan de enheter som första gången förekom 1870-1910 respektive 1930-1945 framträder bara små förändringar. Enheter med fyra eller fler syskon blev något fler 1930-1945, men å andra sidan blev enheterna med tre färre. ${ }^{401}$ Skillnaden gentemot de syskonjordbruk som förekom 1971-1991 är emellertid betydande. Dessa var visserligen inte så många (totalt 36 stycken), men bland dem fanns enbart två enheter med tre syskon och två med fyra. På resterande 32 jordbruk bodde enbart två syskon. Nedgången i antalet syskonjordbruk under andra halvan av 1900-talet sammanföll med andra ord med en påtaglig tillbakagång av brukningsenheter med fler än två syskon. Som kommer att framgå sammanföll denna utveckling med att flera andra utmärkande drag hos syskonjordbruken förändrades. 


\section{Bröder och systrar}

Vid sidan om att fastställa antalet syskon är det viktigt att undersöka fördelningen mellan könen. Den var mycket jämn på de gårdar där det bodde fyra, fem eller sex arvingar. Syskonen Törnkvist på Göksätter var på intet sätt unika; på samtliga syskonjordbruk med fyra eller fler individer bestod de samboende av både bröder och systrar, sammantaget var de dessutom exakt lika många. ${ }^{402} \mathrm{På}$ enheterna med två eller tre arvingar varierade fördelningen mer, vilket framgår av tabell 4.10.

Tabell 4.10. Könsfördelning på 233 syskonjordbruk med två eller tre syskon, 1870-1991.

\begin{tabular}{cccccccc|}
\multicolumn{3}{c}{} & \multicolumn{3}{c}{ Två syskon } & \multicolumn{3}{c}{ Tre syskon } \\
\cline { 2 - 4 } & Bröder & Systrar & Blandat & Bröder & Systrar & Blandat \\
Antal & 67 & 20 & 93 & 11 & 7 & 35
\end{tabular}

Källa: Se källangivelser under tabell 4.2.

Allmänt sett präglades syskonhushållen av en blandad sammansättning. Både på två- och tresyskonjordbruken var det vanligast att hushållet bestod av både bröder och systrar, och totalt var nära 60 procent av alla syskonjordbruk könsblandade. Den enskilt vanligaste konstellationen, vilken återfanns på mer än en tredjedel av enheterna, var en gård med en bror och en syster. I de enkönade hushållen övervägde männen kraftigt, och sammantaget bestod mer än vart fjärde syskonjordbruk av två bröder. På de 259 syskongårdarna fanns totalt 633 personer, varav 369 män ( 58 procent) och 264 kvinnor (42 procent). ${ }^{403}$ Det fanns med andra ord i genomsnitt en syster per syskonjordbruk, men nästan en och en halv bror. Systrarna var inte heller jämnt fördelade - de lyste helt med sin frånvaro på nästan vart tredje syskonbruk. Att systrar ändå ingick i de flesta syskonhushåll är tankeväckande, särskilt mot bakgrund av att tidigare forskning visat att det under 1800-talet var sällsynt att döttrar fick överta jord. ${ }^{404}$ Det är dock svårt att enbart utifrån hushållets sammansättning sluta sig till vilka positioner arvingarna hade i förhållande till varandra. Som framgick i förra kapitlet tycks det inte sällan ha förekommit att en bror övertog gården och att 
systern fick ta hand om hans hushåll. En central fråga är därför i vilken utsträckning systrar ägde andelar i jorden och längre fram i kapitlet undersöker jag ägandeförhållanden vidare.

Går det att skönja några ytterligare mönster ifråga om könsfördelning? Bröder var något mindre förekommande i småbrukarsocknarna än i socknarna med större gårdar, men skillnaden uppgår inte till mer än en eller två procentenheter. ${ }^{405}$ Mellan de syskonjordbruk som uppkom 1870-1910 respektive 1930-1945 finns inte heller några påtagliga skillnader. Andelen syskonjordbruk med blandad sammansättning var i båda dessa kategorier 62 procent och runt var fjärde bestod enbart av bröder. Fram till perioden 1971-1991 förändrades antalet syskon kraftigt och tvåsyskonjordbruken blev helt dominerande. Inslaget av bröder ökade också kraftigt. Inte ett enda syskonhushåll under denna period saknade män och andelen gårdar med könsblandad sammansättning sjönk från 62 till 38 procent. Följden blev att jordbruk med två bröder intog en särställning under denna period, då de utgjorde nästan två av tre syskonenheter.

\section{Civilstånd}

I förra kapitlet konstaterades att ett väsentligt inslag i generationsväxlingarna under 1900-talets första decennier var att många människor förblev ogifta, vilket tycks ha samvarierat med en ökad tendens att arvingar övertog gårdar tillsammans. Hur vanligt var det med äktenskap bland syskonjordbrukarna? Först måste påpekas att det var ovanligt att alla i en syskonskara förblev ogifta. En uppföljning i husförhörslängder och församlingsböcker visar att många syskon gifte sig, men att äktenskapet ofta innebar ett uppbrott från hushållet. Av dem som var kvar på gården var därför inte oväntat en mycket stor andel ogifta: av 633 syskon på de studerade enheterna var hela 531 ogifta, närmare 85 procent. ${ }^{406}$ I fyra hushåll, samtliga under perioden 1971-1991, fanns två gifta syskon: två bröder som båda gift sig men bodde kvar på samma fastighet. Troligen rörde det sig i dessa fall inte om att två familjer delade hushåll utan om att de hade skilda bostäder inom samma fastighet och delade på jordbruket. Eftersom 
hushållsstrukturen inom fastigheten inte framgår i mantalslängderna 1971 och 1991 går det emellertid inte att avgöra och därför har de fyra ändå räknats som syskonjordbruk. ${ }^{407}$

På bara lite mer än vart tredje syskonjordbruk, 95 stycken, fanns ett gift syskon. Uppfattningen att det typiska syskonjordbruket bestod av ogifta syskon visar sig med andra ord stämma. Samtidigt är bilden inte entydig och det finns skäl att utförligare granska de fall där en arvinge gift sig. Förelåg några särskilda förutsättningar i dessa fall? Det finns för det första inga tydliga skillnader mellan olika områden eller tidsperioder. Under den mittersta delperioden ökade giftermålsfrekvensen svagt, men det rör sig om små skillnader och andelen syskonjordbruk med äktenskap låg mellan 36 och 41 procent under alla tre delperioder. Däremot var äktenskapen vanligare ju färre syskonen var. Inte mindre än 78 av äktenskapen fanns på tvåsyskonjordbruken, alltså på en bit över 40 procent av dem. När det fanns fler arvingar var äktenskapet betydligt mer sällsynt. Bara tre av äktenskapen fanns på enheter med fyra eller fler syskon, det vill säga strax över tio procent.

Som framgått tidigare var bröder vanligare bland tvåsyskonjordbruk och detta ger utslag även i giftermålstalen. Av 103 gifta syskon var inte mindre än 79 män. Att systrar gifte sig skedde således enbart i 24 fall, och 16 av dessa rörde enkönade hushåll utan bröder. Det var således främst bröder som gifte sig, men könsfördelningen hade också ett nära samband med äktenskapsmönstret. Delas syskonjordbruken upp i de med könsblandad respektive enkönad syskongrupp framträder en tydlig skillnad.

Tabell 4.11 Äktenskapsfrekvens efter syskongruppens könsfördelning, tio socknar 1870-1991.

$\begin{array}{lccc} & \text { Antal enheter } & \text { Antal äktenskap } & \text { Andel } \\ \text { Enbart bröder } & 78 & 49 & 63 \\ \text { Enbart systrar } & 27 & 16 & 59 \\ \text { Bröder och systrar } & 154 & 38 & 25\end{array}$

Källa: Se källangivelser under tabell 4.2.

Inom den numerärt största typen - enheter med både bröder och systrar - fanns bara i vart fjärde hushåll ett gift syskon, vanligen 
en bror. ${ }^{408}$ Skillnaden gentemot enkönade enheter är markant. På dem var äktenskapsfrekvensen mer än dubbelt så hög och mer än 60 procent omfattade ett gift par. Det innebär sammantaget att nära två tredjedelar av alla äktenskap återfanns på de enkönade gårdarna, som därigenom i praktiken inte var enkönade. Detta mönster indikerar att en nyckel för att förstå syskonjordbrukens dynamik är relationen mellan dess sammansättning och äktenskapsmönstret.

\section{Bröder, systrar och ingifta - positioner och personer}

I sin studie av familjejordbruket i Sverige under 1900-talet argumenterar Iréne Flygare för att kvinnor hade ytterst begränsade möjligheter att överta gårdar och att deras väg in i jordbruket främst bestod av tre traditionella alternativ: gifta sig med en bonde, födas i en bondefamilj med enbart döttrar eller bli änka efter en bonde. ${ }^{409}$ Under en period på 1900-talet fanns det dock ett fjärde alternativ: att ta över gården tillsammans med sina syskon. ${ }^{410}$ Vad innebar det att allt fler systrar stannade kvar på gården tillsammans med sina bröder? Som framgått var merparten av syskonen män. Enkätmaterialet i föregående kapitel tydde på att systerns roll ofta var att ta hand om sina bröders hushåll. Var systrarna enbart en form av hushållerskor medan bröderna var de "riktiga bönderna"? Vilken ställning hade de olika medlemmarna i hushållet? Längre fram i kapitlet ska ägandeförhållandena granskas, men innan dess finns skäl att diskutera hushållets arbetsförhållanden. Bröders, systrars och ingiftas plats i hushållen måste enligt min mening knytas till deras funktion - vad de faktiskt gjorde.

Problemen att fånga hushållets struktur framgår stundtals i folkräkningsmaterialet. I 1945 års folkräkning klassificerades exempelvis hushållsmedlemmar utifrån sina arbetsuppgifter. Personer som biträdde familjeföreståndaren i dennes yrke klassades som förvärvsarbetande, och de som främst ansågs syssla med hemgöromål hänfördes till de icke förvärvsarbetande. Knut Norborg pekar på att denna uppdelning blev särskilt missvisande för kvinnor i jordbruket, eftersom de "ofta delar sitt arbete mellan hemsysslor och jordbruksarbete". ${ }^{411}$ Det är därför knappast förvånande att jordbruket under 1900-talets första hälft enligt den officiella statistiken var en 
manlig domän. Kirsti Niskanen konstaterar att jordbruket på en samhällelig och kulturell nivå var en verksamhet som "bedrevs av en manlig husföreståndare, med hjälp av kvinnor och barn, oavsett hur den faktiska situationen var". ${ }^{412}$

På de flesta av landets jordbruksenheter var kvinnors arbete i jordbruksproduktionen helt avgörande, men det syns sällan i officiell statistik över arbete och arbetskraft eftersom kvinnors arbete inom jordbruket definierades bort vid insamlingen av de statistiska uppgifterna. Folkräkningarna definierade enligt Anna Nyberg länge generellt jordbrukarhustrur som arbetande i hushållet och inte i jordbruket. Så sent som 1950 räknades hustrur som förvärvsarbetande enbart om hushållsarbetet tydligt åvilat någon annan i hushållet. ${ }^{413}$ Baserat på en analys av nära tusen jordbrukarhustrur kan dock Nyberg visa att kvinnorna i praktiken ägnade en stor del av arbetsdagen åt jordbruket. De skötte djur, mjölkade, utfodrade, deltog i skördearbete och sålde de varor som jordbruket producerade. ${ }^{414}$ Arbetet inne och ute flöt in i vartannat. Idén att kvinnan i huvudsak arbetat inne med hushållsgöromål är sen och rör en mycket kort tid i mitten av 1900-talet. ${ }^{415}$ Kirsti Niskanen framhåller att kvinnor och män inte utförde samma arbetsuppgifter och att genusarbetsdelningen inte enbart var en "social organisation av könsskillnaderna" utan även "kulturellt grundade begrepp om hur dessa skillnader fungerar" ${ }^{416}$ Hon understryker vikten av att inkludera kvinnors arbete i analysen och pekar på hur statistikens och nationalekonomins ideologiimpregnerade data från viss tid kom att urskilja kvinnors hushållsarbete som improduktivt.

Baserat på folkminnesmaterial från 1900-talets landsbygd argumenterar Anders Perlinge för att kvinnan var en nödvändig förutsättning för att jordbruk alls skulle kunna bedrivas. Dels krävde många arbetsmoment två personer, dels var en del sysslor i praktiken otänkbara för män att utföra "då de utmanade allmänt omfattande könsrollsmönster eller kulturellt bestämda vanor" ${ }^{417}$ Kvinnor hade ofta hand om mjölkning, ladugårdsarbete och det inre hushållet, samt arbetade ute i samband med arbetstopparna, men Perlinge understryker deras flexibilitet: "den duktiga husmodern i jordbrukarhemmet skulle kunna klara av allting, både inomhus och 


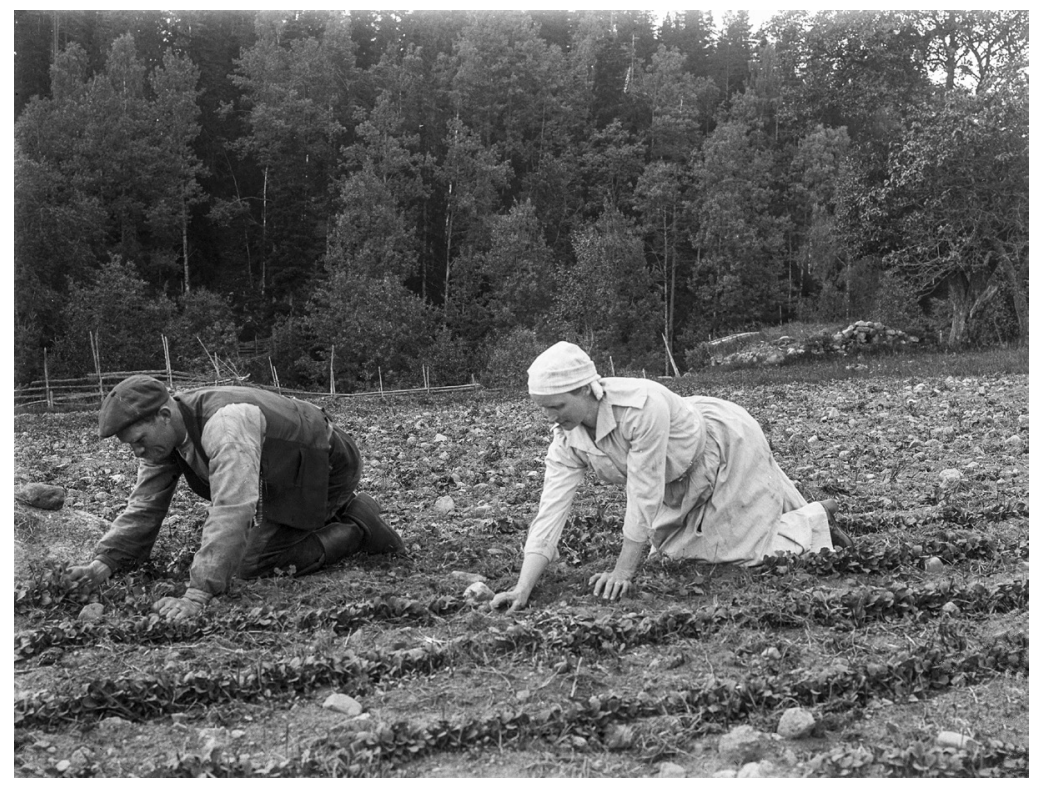

Män och kvinnor har ofta haft skilda arbetssfärer inom jordbruket, men i vissa sysslor gjordes ingen skillnad på kön. Rensning och gallring av rovor i Svinhults socken, Östergötland, 1920. Foto: August Christian Hultgren/Östergötlands museum.

utomhus". ${ }^{418}$ På små gårdar, där männen efter hand började med mycket utgårdsarbete, fick kvinnorna ofta ta huvudansvaret även för traditionellt manliga sysslor i jordbruksarbetet. ${ }^{419}$

Att kvinnors arbete var omistligt på gården understryker äktenskapets betydelse. Perlinge, Nyberg och Niskanen utgår alla från att genusarbetsdelning inom jordbruket löstes genom äktenskapet, som fick rollen att komplettera hushållets sammansättning. Det är således föga förvånande att äktenskapet var vanligare i enkönade syskonhushåll: både kvinnor och män behövdes i jordbruksarbetet. Det intressanta resultatet är att äktenskap sällan ingicks när syskonskaran redan från början innehöll både bröder och systrar. Med utgångspunkt i det arbete som bedrevs ligger det nära till hands att förklara detta med att det då inte fanns samma behov att komplettera hushållets arbetskraft. Positionerna var upptagna. Att det redan fanns någon som utförde sysslorna innebar i sin tur sannolikt att det blev svårare för en utomstående äktenskapspartner att finna sin 
plats på gården. En ingift man måste konkurrera med sina svågrar om husbonderollen, och en hustru bör ha ställts inför ett minst lika minerat fält i förhållande till sina svägerskor om husmorspositionen. I nästa kapitel utforskar jag dessa spänningar närmare. Det finns dock skäl att peka på ytterligare en position med betydelse - föräldrarna.

\section{Den äldre generationen}

I enkätsvaren i kapitel 3 framskymtade en utveckling där föräldrarna behöll det formella innehavet av gården långt upp i åren. En del uppgifter pekade på att arvskiftet kunde uppskjutas till dess att båda föräldrarna avlidit. Många syskonhushåll bör således ha inkluderat någon ur föräldragenerationen. Två viktiga frågor i detta sammanhang är därför hur vanligt ett sådant samboende var och vilken roll föräldrarna spelade för syskonjordbrukets uppkomst. Bodde syskonen kvar till följd av föräldrars uttalade vilja eller till följd av deras brist på beslut?

Tabell 4.12. Antal (andel) syskonjordbruk med kvarboende föräldrar, tio socknar 1870-1991.

$\begin{array}{lc}\text { Kvarboende i hushållet } & \mathbf{1 8 7 0 - 1 9 1 0} \\ \text { Båda föräldrarna } & 8(10) \\ \text { Modern } & 18(23) \\ \text { Fadern } & 7(9) \\ \text { Minst en förälder } & 33(42)\end{array}$

$\begin{array}{cc}\mathbf{1 9 3 0 - 1 9 4 5} & \mathbf{1 9 7 1 - 1 9 9 1} \\ 18(12) & 1(3) \\ 37(25) & 3(8) \\ 16(11) & 2(5) \\ 71(48) & 6(16)\end{array}$

Källa: Se källangivelser under tabell 4.2.

Anm.: Föräldrar har enbart medräknats om de enligt folkräkningsmaterialet ingick i hushållet, inte om de bodde kvar på samma fastighet men hade eget hushåll, till exempel i en undantagsstuga.

Att föräldrar bodde kvar med sina vuxna barn förekom fram till mitten av 1900-talet på nästan vartannat syskonhushåll. Under seklets senare hälft var det betydligt sällsyntare, och eftersom antalet syskonjordbruk samtidigt minskade rör det sig dessutom om få fall. Variationerna i när gården överläts var emellertid stora. Det fanns föräldrar som redan i 50-årsåldern lämnade över ansvaret för gården till barnen, men också de som ännu stod kvar som 
ansvariga när barnen var i 50-årsåldern. Ett mer beständigt drag var vilken förälder som fanns kvar. Mödrar var under hela undersökningsperioden betydligt vanligare än fäder och fanns fram till 1945 i ungefär vart tredje syskonhushåll.

Vilken roll spelade föräldragenerationen i syskonjordbrukens uppkomst? Verkade de aktivt för att flera av barnen skulle vara kvar och driva gården tillsammans, eller sökte de undvika en sådan utveckling? Bland de 259 syskonenheterna finns 38 gårdar där föräldragenerationen vid första observationen formellt inte hade lämnat över ansvaret trots att det fanns flera barn över 35 år i hemmet. ${ }^{420}$ Var det ett steg på vägen mot att arvingarna så småningom övertog gemensamt, eller speglar det en försenad generationsväxling där så småningom ett av barnen tog över och de andra gav sig av? Följs de 38 familjerna till nästkommande nedslagsår visar sig det senare ha varit mycket ovanligt. Enbart i tre fall tog en arvinge ensam över gården. Det vanligaste var att gården formellt hade övergått på barnen och att sammanboendet fortgått. ${ }^{421}$ När föräldrarna undvek att själva ordna successionen så länge att de hemmavarande barnen passerat 35-årsstrecket var det således ett stort steg på vägen mot att syskonen förblev i hemmet.

Att föräldrarna under sin livstid skrev över gården på flera av barnen var inte särskilt vanligt, men det skedde i åtminstone tio familjer i mitt material. Det antyder onekligen att det gemensamma övertagandet i dessa fall var planerat. Vanligare var dock att ett barn - en son - favoriserades. I både folkräkningarna och husförhörslängderna finns det flera exempel på att en son i materialet betecknats som hemmansägare samtidigt som modern bodde kvar i hushållet tillsammans med en dotter eller ytterligare söner. I vilken ordning hushållets medlemmar förtecknades i materialet har ingen praktisk betydelse för klassificeringen som syskonjordbruk - sammansättningen var densamma - men den symboliska innebörden är desto större. Det tycks i dessa fall inte ha funnits en direkt intention hos föräldragenerationen att skapa ett syskonhushåll, utan snarast att åstadkomma en traditionell generationsväxling där en arvinge ensam övertog gården. Att ytterligare syskon i sådana fall ändå blev kvar kan ha flera förklaringar, men en möjlig tolkning är att arrangemanget hade att göra med omvårdnad av de äldre. ${ }^{422}$ 
Vad gäller föräldrarnas närvaro i hushållen framträder inga påtagliga skillnader mellan de tio socknarna, och den varierade heller inte i någon påfallande grad med syskonens antal, civilstånd eller könsfördelning. Tidsmässigt finns dock en skillnad: under den sista delperioden förekom föräldrar uteslutande på enheter med enbart ogifta barn. Det rör sig dock inte om fler än sex fall, så underlaget medger inte några större slutsatser. Ett skäl till att föräldrarna försvann kan ha varit äldrevårdens utbyggnad under efterkrigstiden. En mer närliggande orsak var dock en förändring hos syskonjordbrukarna själva - de blev äldre.

\section{Att bli gammal i gården}

Kännetecknades syskonhushållen av ålderstigna medlemmar eller främst medelålders jordbrukare? Att många enheter innefattade föräldrar antyder att syskonen själva inte var särskilt gamla, men att syskongrupper ofta bara förekom vid ett nedslag och därefter upplöstes av syskonens död pekar i en annan riktning. Eftersom samma syskongrupp inte samtidigt kunde vara både ung och gammal är en tredje möjlighet att det fanns en stor åldersvariation mellan hushållen. En jämförelse av hur åldersstrukturen utvecklades kan ge viktiga pusselbitar för att förstå hur företeelsen syskonjordbruk förändrades över tid. För detta syfte har medelåldern för varje syskongrupp beräknats för de sju nedslagsåren. ${ }^{423}$

Tabell 4.13 Åldersfördelning (syskongruppens medelålder) på 259 syskonjordbruk, tio socknar 1870-1991.

$\begin{array}{lccccccc} & \mathbf{1 8 7 0} & \mathbf{1 8 9 0} & \mathbf{1 9 1 0} & \mathbf{1 9 3 0} & \mathbf{1 9 4 5} & \mathbf{1 9 7 1} & \mathbf{1 9 9 1} \\ \text { Under 40 år } & 3 & 14 & 15 & 37 & 20 & 4 & 1 \\ 40-50 \text { år } & 4 & 10 & 17 & 39 & 26 & 8 & 2 \\ 50-65 \text { år } & - & 3 & 18 & 22 & 38 & 20 & 3 \\ \text { Över 65 år } & - & 1 & 4 & 8 & 9 & 10 & 10 \\ \text { Medelålder } & \mathbf{4 2} & \mathbf{4 1} & \mathbf{4 7} & \mathbf{4 4} & \mathbf{5 0} & \mathbf{5 6} & \mathbf{6 3}\end{array}$

Källa: Se källangivelser under tabell 4.2.

Anm.: Vid beräkning av medelåldern vid varje undersökningsår har högsta och lägsta värdet uteslutits. 
Över tid förändrades hushållens åldersfördelning kraftigt. Vid de två första nedslagsåren var medelåldern runt 40 år och bara i en handfull fall över 50. När antalet syskonjordbruk successivt steg framträdde en mer sammansatt bild. Den stora ökningen till 1930 bestod visserligen huvudsakligen av syskon under 50 år, varav en stor del till och med var under 40, men samtidigt uppenbarade sig allt fler äldre syskongrupper. Denna trend blev allt skarpare markerad och från 1930 steg medelåldern med ungefär sex år för varje nedslagsår fram till 1991. Allt färre yngre hushåll tillkom och vid det sista nedslaget hade flertalet av de kvarvarande brukarna passerat normal pensionsålder. Bland syskonjordbrukarna 1991 ingår dessutom tre av de tvåbrödrabruk där båda bröderna gift sig. De bodde på samma fastighet och drev jordbruket gemensamt, men det mest sannolika är att de hade separata hushåll - eventuellt i olika boningshus - och enbart hade gårdsdriften ihop. Dessa hushåll var bland de yngre hushållen 1991 och om de borträknas stiger medelåldern för nedslagsåret till klart över 65 år. Att de ingående syskonen blev allt äldre är rimligen en viktig förklaring till att så få föräldrar ingick i hushållen mot slutet av undersökningen - de var inte längre i livet.

Medelåldern bland syskonjordbrukarna steg från 40 år i slutet av 1800-talet till 63 år drygt ett sekel senare. Förändringen var dramatisk, men var den specifik för syskonenheterna? Hurdan var åldersutvecklingen inom bondebefolkningen i sin helhet? Medelåldern för jordbrukare - beräknat utifrån hushållsföreståndarens ålder - förändrades mycket lite i de tio socknarna under de 120 åren. Vid samtliga undersökningsår låg den mellan 48 och 52 år, utan någon tydlig tendens till långsiktig förändring. ${ }^{424} \mathrm{Vid}$ de två första nedslagen låg medelåldern för syskonjordbruken därmed klart lägre än det totala genomsnittet. När syskonenheterna ökade i antal under 1900-talets första hälft ändrades åldersstrukturen och genomsnittet låg nära medelåldern för samtliga jordbruk, även om det fanns ett stort antal unga syskonjordbrukare $1930 .{ }^{425}$ Under den tid syskonjordbruket var som mest betydelsefullt utgjorde med andra ord inte arvingarnas ålder dess signum. De åldrande arvingarna på syskonenheterna under seklets andra hälft saknade dock motsvarighet i medelåldern för jordbrukarna i stort. Från 
att inledningsvis ha utmärkt sig för att i genomsnitt vara yngre än jordbrukarna i allmänhet, var syskonjordbrukarna mot slutet av undersökningen istället klart äldre.

De fem faktorer jag har redovisat (antal, kön, civilstånd, föräldrar och ålder) visar sammantaget hur syskonhushållens sammansättning förändrades över tid. Inledningsvis delade jag in undersökningsperioden i tre stadier efter syskonjordbrukens antal: en tillväxtperiod 1870-1910, en verklig storhetsperiod 1930-1945, samt en stagnationsperiod 1971-1991. Mellan de två första av dessa stadier finns inga större skillnader: syskonens antal, könsfördelning, äktenskapsmönster och föräldranärvaro förblev i princip desamma fram till 1900-talets mitt. Den enda påtagliga förändringen var att arvingarnas medelålder nådde samma nivå som jordbrukarnas i stort. De syskonjordbruk som uppkom under den tredje delperioden avvek dock på flera punkter från det tidigare mönstret. Systrarna försvann och de kvarvarande syskonen var vanligen två bröder, varav åtminstone en var gift. Arvingarnas medelålder steg kraftigt och föräldrarna fanns sällan kvar på gårdarna. Över tid ändrade syskonjordbruk som företeelse karaktär och i flera avseenden tycks de snabbt ha förgubbats. Hushållens sammansättning ger emellertid inte hela bilden. Hur gården och jordbruket hanterades behöver också beaktas. Hur var jordägandet fördelat mellan arvingarna, hur stora var syskongårdarna och i vilken grad följde de med i den tekniska utvecklingen?

\section{Hur ägdes gården?}

Folkräkningsmaterialet anger i de flesta fall syskonens titlar, vilket ger antydningar om egendomsrelationerna dem emellan. I de fall alla betitlas hemmansägare ligger det nära till hands att tro att ägandet var fördelat dem emellan. I många fall anges dock enbart en arvinge som hemmansägare medan övriga har andra titlar. Mest noterbart är att ett stort antal kvinnor betecknas som "syster" eller "hushållerska". Innebar det att systrarna inte ägde jord i samma utsträckning som bröderna? Folkräkningarnas försök att yrkeskategorisera inte bara hushållen utan även deras olika medlemmar är av visst intresse, men att använda dem som grund för att analysera egendomsrelationer 
är svårt. Dels finns ett antal syskon som helt saknar titlar, särskilt i de fall där jorden ännu formellt var i föräldrarnas händer. Dels är titlarna tänkta att spegla sysselsättningar, inte ägandeförhållanden. ${ }^{426}$ Ett delägande syskon som också sysslade med hantverk tilldelades sannolikt en yrkestitel framför en benämning som delägare. För att analysera egendomsrelationerna på syskonhushållen måste således folkräkningsmaterialet kompletteras med ägandeuppgifter från andra källor.

Det mest tillförlitliga sättet att erhålla uppgifter om hur ägandet var fördelat är att undersöka lagfartsbevisen för respektive enhet. Lagfartsmaterialet saknar emellertid register och en dylik kontroll skulle vara mycket arbetskrävande. En något snabbare väg vore att konsultera de fastighetsböcker som började föras under 1930-talet. ${ }^{427}$ Nackdelarna med det är dock dels att fastighetsbeteckningar kan ha förändrats över tid, dels att fastighetsböckerna bara kan användas för de tre senare nedslagsåren. Istället har jag inhämtat uppgifter om ägande från mantalslängderna vid varje nedslagsår. ${ }^{428} \mathrm{I}$ ett flertal undersökningar har det visats att mantalslängderna under 1800-talet ofta gav en riktig bild av ägandeförhållandena. ${ }^{429}$

Mantalslängderna är emellertid inte oproblematiska. En svårighet är att de förtecknade ägandeuppgifterna primärt gäller innehav på hushållsnivå och inte på individnivå. Det finns exempelvis mycket sällan uppgifter om huruvida äkta makar samägde jord eller om hela egendomen var den ena makens enskilda egendom. Mannen skrevs så gott som alltid som hemmansägare, även om han samägde gården med sin hustru eller om det rentav var hennes enskilda jord. Detta skrivsätt kan förklaras av att den äkta mannen då ändå hade dispositionsrätt till hela egendomen. ${ }^{430}$ För syskonhushåll förhåller sig saken annorlunda. Bröder hade visserligen intill 1890 rätt att lösa ut systrar, men de kunde inte utan vidare disponera deras egendom. En central fråga är följaktligen i vilken utsträckning mantalslängderna korrekt återger ogifta kvinnors tillgångar. I ett par fall varierar skrivsättet i mantalslängderna på ett sätt som gör det troligt att så inte är fallet. En fastighet kan exempelvis vara skriven på en bror "och hans syster", vilket rimligen bör tolkas som att de samägde den. Men den kan också stå skriven på brodern, 
varpå systern är uppräknad som boende i hushållet. Skillnaden kan synas subtil men utgör möjligen en indikator på ägandeförhållandena. För att bedöma mantalslängdernas uppgifter har jag för ett mindre urval fastigheter kontrollerat ägandeförhållandena mot de fastighetsböcker som infördes i början av 1930-talet, utan att finna några avvikelser. Även om det finns vissa frågetecken kring mantalslängdernas ägandeuppgifter finns således skäl att se dem som någorlunda tillförlitliga. De bör i vart fall kunna ge en indikation om vilka ägandemönster som rådde på syskonjordbruken.

Jag har excerperat mantalslängdernas ägandeuppgifter för 1890, 1910, 1930 och 1945. Åren 1971 och 1991 ger dessvärre varken mantalslängderna eller jordbruksregistret några ägandeuppgifter och 1870 var syskonenheterna så få att en uppdelning ter sig meningslös. Arrendegårdar har räknats bort, liksom några enstaka fall med oklara ägouppgifter. De övriga gårdarna har jag delat upp i fem kategorier. Om samtliga kvarboende syskon ägde tillsammans har fastigheten betecknats som allägd. ${ }^{431} \mathrm{Om}$ ägandet var uppdelat på flera, men inte alla, syskon har den betecknats som flerägd. Fastigheter som helt ägdes av en bror eller en syster har särskilts, liksom de som formellt ännu ägdes av föräldrarna. Resultatet framgår i tabell 4.14.

Tabell 4.14. Antal syskonjordbruk med klarlagda ägoförhållanden fördelade på olika ägarkategorier, tio socknar 1890-1945.

\begin{tabular}{lcccccccc} 
& \multicolumn{2}{c}{$\mathbf{1 8 9 0}$} & \multicolumn{2}{c}{1910} & \multicolumn{2}{c}{$\mathbf{1 9 3 0}$} & \multicolumn{2}{c}{$\mathbf{1 9 4 5}$} \\
Enheter & \multicolumn{2}{c}{20} & \multicolumn{2}{c}{43} & \multicolumn{2}{c}{104} & \multicolumn{2}{c}{74} \\
& Antal & Procent & Antal & Procent & Antal & Procent & Antal & Procent \\
Allägda & 9 & 45 & 18 & 42 & 28 & 27 & 30 & 41 \\
Flerägda & 1 & 5 & 1 & 2 & 4 & 4 & 3 & 4 \\
En bror & 9 & 45 & 18 & 42 & 53 & 51 & 30 & 41 \\
En syster & 0 & 0 & 1 & 2 & 7 & 7 & 3 & 3 \\
Föräldraägda & 1 & 5 & 5 & 12 & 12 & 12 & 8 & 11
\end{tabular}

Källa: Se källangivelser under tabell 4.2.

Trots att antalet syskonjordbruk varierade stort över tiden uppvisar ägandeförhållandena ett påfallande stabilt mönster. De enheter som förekom vid flera nedslagsår ändrade vanligen inte ägarkategori, och 
i de fall det hände var det på grund av dödsfall. ${ }^{432}$ Två huvudvarianter framträder: att samtliga kvarboende syskon ägde fastigheten tillsammans och att en bror ensam ägde hela fastigheten. Tillsammans uppgick enheterna i dessa kategorier till mellan 80 och 90 procent vid de fyra studerade åren och vid tre av de fyra åren var de dessutom lika många. Undantaget är 1930, då de brorägda enheterna var ovanligt många, vilket till viss del förklaras av särskilda omständigheter vid det nedslaget: av 1930 års syskonenheter var det ovanligt många som sedermera upplöstes genom att en arvinge stannade och övriga flyttade. Av femton sådana enheter ägdes tio av en bror, så den höga andelen brorägda fastigheter utgjordes delvis av enheter som bara var syskonhushåll en kortare tid. ${ }^{433}$

Trots de kvantitativa likheterna mellan allägda och brorägda gårdar fanns det klara skillnader dem emellan. På de allägda var syskonen ofta fler, och könsfördelningen var mycket jämn. ${ }^{434}$ Dessutom var äktenskap ovanliga på sådana enheter: bara i vart fjärde fall hade någon av arvingarna gift sig. På de brorägda enheterna var syskonen ofta färre, i nästan fyra av fem fall var de bara två. På många sådana enheter fanns därmed en ägande bror och ett kvarboende syskon utan äganderätt. De senare hade ett utmärkande kännetecken: två tredjedelar av dem var kvinnor. Den totalt sett vanligaste konstellationen - en bror och en syster - återfanns i huvudsak inom denna kategori; av de 74 sådana enheter som förekom mellan 1890 och 1945 var brodern ensam ägare i 50 fall, systern i ett enda. I jämförelse med allägda fastigheter var äktenskapen något vanligare på de brorägda, där ungefär var tredje var gift.

Allägda och brorägda fastigheter dominerade således, och flerägda fastigheter var ett slags hybrid mellan de två. I samtliga sådana fall ägde två bröder gården tillsammans samtidigt som andra syskon nästan alltid systrar - fanns kvar i hushållet. ${ }^{435}$ Bara elva av gårdarna ägdes av en syster ensam. I samtliga fall var hon gift och i alla fall utom ett saknades kvarboende bröder. På de föräldraägda gårdarna, i likhet med på de allägda, var äktenskap ovanliga. Knappt i vart färde fall hade någon gift sig, och det var uteslutande bröder. Ett annat kännetecken för föräldraägda fastigheter var att de kvarboende syskonen var ovanligt många, i medeltal 2,9 personer. ${ }^{436}$ 
Analysen visar att ägandeförhållandena varierade men kanske framför allt att syskonjordbruken inte i huvudsak var en möjlighet för kvinnor att behålla sin jord. Visserligen fanns det många fall där alla arvingar ägde sin andel och där systrar ifråga om jordägande hade samma positioner som sina bröder. Men kvinnor ägde bara när alla ägde. Var ägandet ojämnt fördelat inom syskonskaran var det kvinnorna som stod utan. Detta mönster förstärktes med all sannolikhet efter 1945, då systrar blev ovanligare i hushållen. Sannolikt speglade egendomens fördelning mellan arvingarna någon avsikt hos föräldrarna. Varför skulle en arvinge ha hela jorden om tanken redan från början var att flera barn skulle förbli hemma? Ur ett sådant perspektiv framstår de många brorägda enheterna som följden av en plan att få till stånd en klassisk generationsväxling där en son ensam övertog gården, men så blev ett eller flera syskon av olika skäl kvar.

Vad har då detta för praktisk innebörd? Spelade den ojämna fördelningen av ägandet någon roll? Det är inte säkert att en utomstående betraktare såg någon skillnad mellan de enheter där alla ägde jorden och de där enbart en bror ägde. Givet att syskonen bodde kvar behöver det inte ha inneburit så mycket i det vardagliga livet heller. Det går dock inte att bortse från att den som bodde kvar utan att ha del i egendomen hade en betydligt osäkrare ställning än en delägare. Den senare kunde knappast köras på porten, men för ett icke-delägande syskon fanns vid eventuella konflikter eller plötsliga krissituationer inte samma säkerhet. Att det i första hand var ogifta systrar som hamnade på mellanhand som hushållerska åt sin bror överensstämmer väl med resultaten från enkätundersökningen i förra kapitlet och understryker att kvinnor kunde ha en utsatt position på många syskonjordbruk.

Det var inte bara på syskongårdarna som hushållerskor återfanns. Regleringen av det husliga arbete som utfördes av hushållerskor, hembiträden och andra befann sig i stark omvandling under 1900-talets första decennier och det går att urskilja en strävan att professionalisera denna typ av arbete. ${ }^{437}$ Efterfrågan på huslig arbetskraft steg från 1800-talets mitt, särskilt i städerna. Med framväxten av en ekonomiskt välbeställd medelklass blev hemhjälp 
en statusmarkör. ${ }^{438}$ Något decennium in på 1900-talet uppstod emellertid en brist på huslig arbetskraft, vilket föranledde politiska åtgärder. Karin Carlsson visar att tanken på social hemhjälp under 1930-talet kopplades till låga födelsetal och understryker att svårigheten att få tag i hemhjälp ansågs leda till att såväl hushållens organisering som reproduktion undergrävdes. ${ }^{439}$

Att det avlönade husliga arbetet utfördes av ogifta kvinnor var självklart. I folkräkningsmaterialet går det att urskilja en tendens att beteckna ogifta kvinnor i hemmiljö som huslig arbetskraft. Vid de första nedslagen betecknades icke-delägande systrar ofta som systrar, det vill säga utifrån sitt släktförhållande till den ägande brodern. Men från och med 1910 års folkräkning blev det vanligare att de betecknades som hushållerskor, vilket flyttade fokus till de husliga arbetsuppgifterna och snarast jämställde dem med annan anställd arbetskraft. De befann sig således i en spänningsfylld position mellan att tillhöra den egendomsägande inre kretsen och att vara anställda. Som kommer att framgå i nästa kapitel innebar det på flera sätt en osäker ställning.

\section{Stora eller små gårdar}

För att undersöka syskonjordbrukens kännetecken delade jag tidigare i kapitlet in de tio socknarna i fem småbrukarsocknar och fem socknar med större jordbruk. Det visade sig att syskonhushållen inledningsvis var vanligare i socknar med större jordbruk, men att det gradvis skedde en övergång så att de från 1930 var vanligare i småbrukarsocknar. Inom en och samma socken fanns dock variationer i jordbrukens storlek, och för att mer bestämt kunna bedöma syskonjordbrukens bärkraftighet krävs en gradering av varje enskild enhet och en möjlighet att jämföra dem. Ännu en bit in på 1900-talet delades gårdar huvudsakligen in efter de gamla mantalsbråken. Ett alternativ vore därför att utgå från mantalsgraderingen i mantalslängderna. Mantalsuppgifterna har i tidigare studier visat sig fungera bra för jämförelser av gårdars bärkraftighet inom ett begränsat område. ${ }^{440}$ Eftersom korrelationen mellan mantal och odlad areal dock varierade över landet är mantalsbråket 
mindre lämpligt när man som i detta fall vill jämföra gårdar från olika delar av Sverige. ${ }^{441}$ I 1945 års folkräkningsmaterial återges emellertid åkerarealen på respektive jordbruksenhet, och fördelen med att använda de uppgifterna är att resultaten kan ställas mot den indelning av gårdar i olika storleksgrupper som gjordes av 1942 års jordbrukskommitté och senare låg till grund för efterkrigstidens jordpolitik. I tabell 4.15 har jag delat in 1945 års syskonjordbruk i ett antal storleksgrupper.

Tabell 4.15. 1945 års brukningsenheter grupperade efter åkerareal, tio socknar.

\begin{tabular}{|c|c|c|c|c|c|c|}
\hline & $2-5$ ha & $5-10$ ha & $10-20$ ha & 20-30 ha & $30-60$ ha & $>60$ ha \\
\hline Enheter & 224 & 174 & 147 & 74 & 61 & 20 \\
\hline $\begin{array}{l}\text { Varav syskon- } \\
\text { jordbruk (andel) }\end{array}$ & $30(13)$ & $25(14)$ & $18(12)$ & $7(9)$ & $13(21)$ & 0 \\
\hline Syskon per enhet & 2,4 & 2,5 & 2,7 & 3,2 & 2,9 & 0 \\
\hline
\end{tabular}

Källa: Församlingsboksutdrag 1945 för Boglösa, Runtuna, Vårdsberg, Femsjö, Furuby, Ullstorp, Dannike, Ekby, Hackvad och Undersvik (RA).

De flesta syskonjordbruken fanns inom de två numerärt största intervallen, det vill säga upp till tio hektar. Det iögonfallande är dock att andelen är hög även i några av de övre storleksklasserna. Mest påtagligt är det i intervallet 30 till 60 hektar, där mer än var femte enhet drevs av syskon. I 1947 års jordbruksbeslut gjordes indelning i ofullständiga jordbruk (upp till 1o hektar), basjordbruk (10-20 hektar), normjordbruk (20-30 hektar) och övriga (över 30 hektar). De allra flesta syskongårdar skulle alltså ha klassats som ofullständiga. ${ }^{442}$ Många av dem hade således dåliga förutsättningar i det långa loppet och riskerade nedläggning inom de följande decennierna. Men att många syskonenheter var småbruk är knappast uppseendeväckande; av de svenska jordbruken var nästan 80 procent under tio hektar $1945 .{ }^{443}$ Mer uppseendeväckande är att så många av dem tillhörde de högre arealgrupperna. De var bärkraftiga enheter som låg väl i linje med efterkrigstidens jordbrukspolitik. I sin studie av jordmarknaden i några starkt kommersialiserade nederländska områden finner Richard Paping ett likartat mönster. De syskonhushåll som där uppenbarade sig under 1900-talet fanns i större 
utsträckning bland de större jordbruken och var rentav vanligast på riktigt stora gårdar om mer än 50 hektar. Ett utmärkande drag var att släktkontinuiteten var mer markerad på de större gårdarna, och Paping tolkar syskonstrukturen på sådana enheter som ett tecken på att familjen varit mån om att hålla gården i släkten. ${ }^{444}$

Uppdelningen av gårdarna i storleksgrupper gör det möjligt att undersöka effekten av två andra faktorer. Nederst i tabellen ovan anges hur många syskon som ingick i syskonjordbruk inom respektive storleksintervall. Visserligen är antalet enheter inom varje storleksintervall litet och bör tolkas försiktigt, men det övergripande mönstret är tydligt: antalet syskon ökade med åkerarealen. Medan det i genomsnitt gick 2,5 syskon på de mindre enheterna var de snarare runt tre på de större. På de senare var syskonen dessutom äganderättsligt mer jämbördiga. För nedslagsåret 1945 utgjorde allägda och brorägda syskonjordbruk 41 procent vardera, men dessa kategorier var inte jämnt fördelade över storleksklasserna. De allägda enheterna var i huvudsak större gårdar. Av enheter över tio hektar utgjorde de hälften, medan enbart en fjärdedel ägdes av en bror. Bland de minsta gårdarna var förhållandet det motsatta: hälften var brorägda och en fjärdedel allägda. En försiktig slutsats är med andra ord att mindre fastigheter oftare ägdes av en bror och beboddes av färre syskon, under det att de större oftare ägdes gemensamt av flera samboende arvingar. Skillnaderna var dock inte knivskarpa och en mer allmän slutsats är att syskonjordbruken uppvisar en stor spännvidd, från små enheter med få syskon där jordbruket sannolikt kompletterades med lönearbete till påfallande många stora bondejordbruk med flera samboende syskon.

Som framgått tidigare i kapitlet förändrades syskonjordbruken påtagligt efter 1950, dels genom att de blev färre, dels genom att deras sammansättning förändrades. Skedde en liknande förändring i storleksförhållandena? Strukturomvandlingens effekter var långtgående i de studerade områdena. Antalet brukningsenheter minskade från 700 till 277 mellan 1945 och 1991. Också storleksfördelningen förändrades. Inom den tidigare dominerande kategorin om enheter upp till tio hektar försvann mer än fyra av fem jordbruk, samtidigt som stora gårdar ökade kraftigt. Jordbruk 
från 30 hektar och uppåt hade enbart utgjort 11 procent 1945 men var ett knappt halvsekel senare fyra gånger så vanliga. En antydan om hur väl syskonjordbruken följde denna utveckling finns i tabell 4.16, där 1991 års enheter är indelade i storleksgrupper.

Tabell 4.16. Syskonjordbruk 1991 efter åkerareal, tio socknar.

$\begin{array}{lccccc} & \mathbf{2 - 1 0} \text { ha } & \mathbf{1 0 - 2 0} \text { ha } & \mathbf{2 0 - 3 0 ~ h a ~} & \mathbf{3 0 - 6 0} \text { ha } & >\mathbf{6 0} \text { ha } \\ \text { Enheter } & 77 & 45 & 35 & 70 & 50 \\ \text { Syskonjordbruk (andel) } & 8(10) & 2(4) & 1(3) & 3(4) & 2(4)\end{array}$

Källa: Lantbruksregistrets primäruppgifter för 1991 för Boglösa, Runtuna, Vårdsberg, Femsjö, Furuby, Ullstorp, Dannike, Ekby, Hackvad och Undersvik (SCB).

Syskongårdarna fanns i alla storleksgrupper men i betydligt större utsträckning bland mindre enheter. Jordbruk i storleken två till tio hektar utgjorde bara runt en fjärdedel av alla brukningsenheter 1991, men hälften av syskonjordbruken räknades dit. ${ }^{445}$ Bland de större jordbruken återfanns dessutom två av de gårdar som drevs av två gifta bröder tillsammans. ${ }^{446}$ Över tid förändrades med andra ord mönstret. Medan de syskonhushåll som fanns kvar 1991 främst fanns på småbruk var de 1945 mer utspridda mellan olika storleksklasser och allra vanligast på stora brukningsenheter. Åkerarealen ger emellertid inte hela bilden. Det är tänkbart att många syskonjordbruk var stora, men att de till följd av sin struktur inte förmådde eller prioriterade att hänga med i jordbruksutvecklingen. Avslutningsvis finns därför också skäl att titta på graden av mekanisering.

\section{Rationalisering eller stagnation?}

I kapitel 1 framhölls att sentida skildringar av syskon i jordbruk ofta baseras på ålderdomliga jordbrukstekniker. Verksamheten har rullat på i invanda mönster och det mesta har förblivit som det en gång var, vilket ger en antydan om att mekaniseringstakten har varit låg på syskongårdarna. Frågan är i vilken utsträckning den bilden stämmer. Varken folkräkningarna eller mantalslängderna ger någon ledning om den tekniska utvecklingen, men för 1945 års nedslag är det möjligt att följa upp gårdarna i 1944 års jordbruksräkning. 


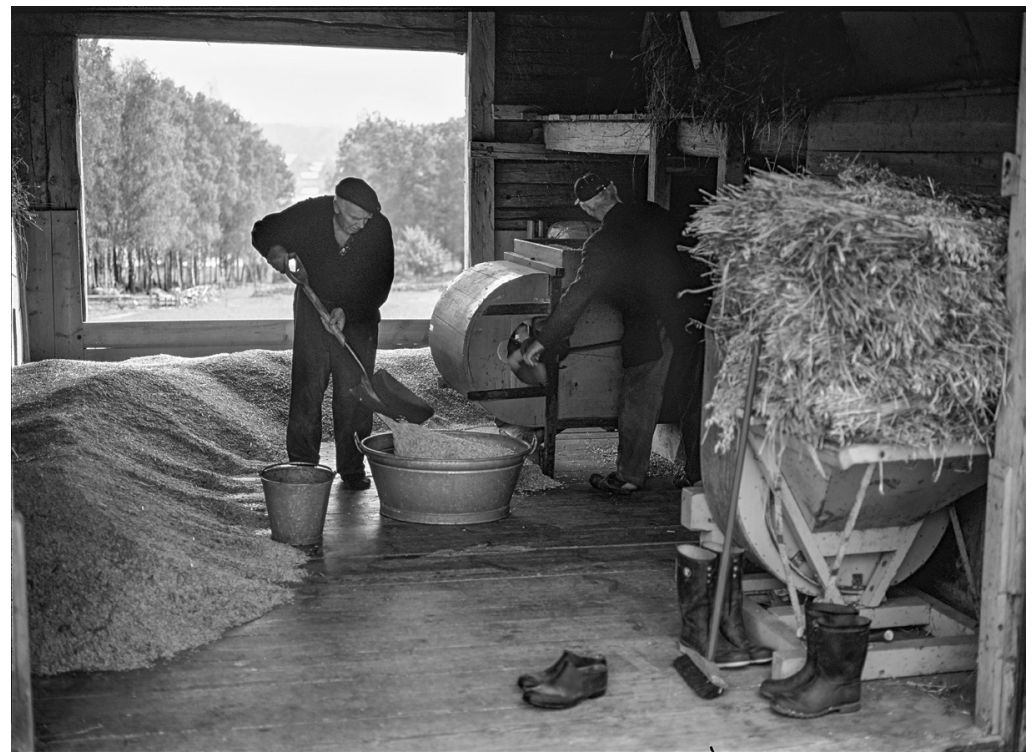

I bilden av syskonjordbruket utgör ofta ålderdomliga brukningsmetoder ett viktigt tema. Erik och Sigvard tröskar säd. Foto: Torsten Axelsson.

Visserligen var det snarast under det efterföljande decenniet som den tekniska utvecklingen tog fart på allvar, men förhållandena 1944 bör ändå ge en fingervisning om huruvida syskonjordbruken skilde sig från mängden.

Tillvägagångssättet för att studera mekaniseringsgraden har varit följande: Primäruppgifterna från jordbruksräkningen, det vill säga det formulär som jordbrukarna själva fyllde i, har granskats för de tio socknarna och de syskonjordbruk som identifierats i 1945 års folkräkning har kopplats ihop med rätt blankett. Eftersom mekaniseringsgraden torde ha haft ett nära samband med brukningsenheternas storlek delade jag in samtliga gårdar efter åkerareal och undersökte samtliga primäruppgiftsblanketter för respektive storleksklass. I formulären fick jordbrukarna fylla i data om arealer och den tekniska nivån på gården i form av vattenledningar, täckdikning, gödselvård, elektrisk kraft samt förekomst av ett drygt tjugotal redskap och maskiner. För att göra jämförelsen överskådlig har jag begränsat undersökningen till tre redskap: 
traktorer, mjölkmaskiner och elmotorer. Samtliga dessa kan sägas ha karaktäriserat teknikutvecklingen i det svenska jordbruket under 1930- och 1940-talen.

Landsbygden elektrifierades successivt från 1910-talet, men elektriciteten användes inledningsvis mest till belysning. Först under mellankrigstiden började elkraft också nyttjas i jordbruket. ${ }^{447}$ Användningen varierade dock med gårdsstorlek. Enligt 1938 års jordbruksutredning, som byggde på ett stort urval gårdar i olika storlekssegment och landsändar, begagnade bara runt hälften av landets jordbruk elektrisk kraft. ${ }^{48}$ Höga installationskostnader i kombination med låga arbetskostnader gjorde att maskinmjölkning inte slog igenom på allvar förrän mot slutet av 1930-talet, men då gick omställningen å andra sidan i rasande fart. ${ }^{449}$ Traktorernas intåg var visserligen i huvudsak ett efterkrigsfenomen, men på de något större jordbruken blev traktorerna vanliga redan på 1930-talet. ${ }^{450} \mathrm{I}$ 1938 års jordbruksutredning fanns traktorer på knappt hälften av gårdarna i spannet 30-50 hektar och en fjärdedel av gårdarna om 20-30 hektar. På mindre enheter var de mer ovanliga. ${ }^{451}$

Förekomsten av elmotorer, mjölkmaskiner och traktorer bland syskonjordbruken borde därmed kunna säga något om teknikutvecklingen på syskonjordbruken och hur väl de hängde med sin tid. Jordbruksräkningen 1944 redovisade maskintillgången på aggregerad nivå, men eftersom den tekniska utvecklingen varierade inom landet och de tio undersökta socknarna inte är valda för att de speglar landet som helhet beräknade jag förekomsten genom att analysera samtliga blanketter från de tio socknarna. ${ }^{452}$ Resultatet redovisas i tabell 4.17 .

Tabell 4.17. Andel jordbruk (procent) med traktor, mjölkmaskin och elmotor inom olika storleksgrupper, tio socknar 1944.

$\begin{array}{lcccccc} & \mathbf{2 - 5} \text { ha } & \mathbf{5 - 1 0} \text { ha } & \mathbf{1 0 - 2 0} \text { ha } & \mathbf{2 0 - 3 0} \mathbf{h a} & \mathbf{3 0 - 5 0} \text { ha } & >\mathbf{5 0} \text { ha } \\ \text { Antal jordbruk } & 233 & 181 & 143 & 85 & 59 & 31 \\ \text { Traktorer } & 1 & 2 & 10 & 49 & 56 & 94 \\ \text { Mjölkmaskiner } & 2 & 10 & 24 & 61 & 73 & 97 \\ \text { Elmotorer } & 22 & 46 & 65 & 78 & 97 & 100\end{array}$

Källa: Primäruppgifter, formulär A1, Jordbruksräkningen 1944. 
Som framgår av tabellen varierade mekaniseringsgraden kraftigt mellan olika storleksklasser. Bland de minsta jordbruken fanns traktorer enbart på två enheter, motsvarande en procent, bland gårdarna över 50 hektar på så gott som alla. Elmotorer fanns på drygt vart femte jordbruk om 2-5 hektar och ökningen var därefter mycket jämn upp till enheter över 30 hektar. För traktorer och mjölkmaskiner förefaller däremot en relativt skarp gräns ha gått vid runt 20 hektar. På mindre jordbruk var de ovanliga, ovanför denna gräns var de snarare regel än undantag. ${ }^{453}$ Frågan är i vilken utsträckning syskongårdarna följde det allmänna mönstret. ${ }^{454}$

Tabell 4.18. Andel syskonjordbruk (procent) med traktor, mjölkmaskin och elmotor inom olika storleksgrupper, tio socknar 1944.

$\begin{array}{lcccccc} & \mathbf{2 - 5} \text { ha } & \mathbf{5 - 1 0} \text { ha } & \mathbf{1 0 - 2 0} \text { ha } & \mathbf{2 0 - 3 0} \mathbf{h a} & \mathbf{3 0 - 5 0 ~ h a ~} & >\mathbf{5 0} \text { ha } \\ \text { Antal syskonjordbruk } & 27 & 32 & 13 & 6 & 11 & 1 \\ \text { Traktorer } & 0 & 3 & 8 & 33 & 36 & 100 \\ \text { Mjölkmaskiner } & 0 & 13 & 15 & 67 & 82 & 100 \\ \text { Elmotorer } & 19 & 41 & 77 & 67 & 100 & 100\end{array}$

Källa: Se källangivelser under tabell 4.17.

Överlag tycks de mindre syskonenheterna ha följt det övergripande mönstret. Elmotorer var visserligen något ovanligare på enheter under 10 hektar, men å andra sidan många inom storleksklassen 10-20 hektar. På de lite större enheterna var skillnaderna större, men inte helt entydiga. Den tydliga brytpunkten runt 20 hektar är tydlig vad gäller andelen gårdar med mjölkmaskin, men inte på samma sätt vad gäller traktorer. Traktorer fanns på ungefär en tredjedel av gårdarna om 20-50 hektar, vilket är klart lägre än genomsnittet för sådana enheter i de tio socknarna. ${ }^{455}$ Antalet syskonjordbruk inom respektive storleksgrupp är dock litet, särskilt bland de större enheterna, och tolkningar blir därför osäkra. En försiktig slutsats är att syskonjordbruken i mitten av 1940-talet knappast låg i framkant av den tekniska utvecklingen, men inte heller skilde ut sig som påtagligt undermekaniserade. 


\section{En stabil struktur i förändring}

I detta kapitel har jag undersökt jordbrukarhushåll i tio socknar mellan 1870 och 1991. Ett tydligt resultat är att syskonjordbruk under denna period gick från att vara ett så gott som okänt fenomen till att på 1930- och 1940-talen utgöra vart sjätte jordbruk. Det finns emellertid ytterligare en omständighet som belyser omfattningen. Syskonhushållen i studien uppkom undantagslöst på enheter som överfördes inom familjen. De var således en följd av ett generationsskifte. På landsbygden fanns emellertid också många gårdar som gick i handel på marknaden istället för att överföras inom släkten. På grundval av uppgifter från 1938 års jordbruksutredning har Mats Morell uppskattat att runt 80 procent av jordbruken i mitten av 1930-talet hade genomgått minst ett generationsskifte. ${ }^{456}$ Andelen fastigheter som har ärvts, i betydelsen att de överförts inom släkten, har fluktuerat över tid men variationen tycks ha varit begränsad. Baserat på ett urval om drygt 200 gårdar kunde jag i en tidigare studie visa att andelen ärvda gårdar under perioden 1865-1945 varierade mellan 59 och 72 procent. De högre nivåerna kännetecknade 1900-talet. ${ }^{457} \mathrm{Om}$ analysen avgränsas till de ärvda enheterna, vilka enligt Morells beräkningar uppgick till fyra femtedelar av alla gårdar, bör några decennier in på 1900-talet uppemot vart femte generationsskifte ha resulterat i att flera arvingar blev kvar på gården. Syskonjordbruk var med andra ord inte något fenomen i marginalen, de utgjorde en väsentlig del av det tidiga 1900-talets agrara struktur.

Det fanns således under en period påfallande många syskongårdar, men få av dem återfanns vid mer än ett nedslagsår. I en kritik av Cambridgeforskarnas tes om kärnfamiljens universella ställning pekar Lutz K. Berkner på hushållets dynamiska struktur. Även om flertalet hushåll ett enskilt år bestod av kärnfamiljer passerade många en övergångsfas som utvidgad familj. ${ }^{458}$ Berkners resonemang avser dock främst en vertikal utvidgning, där flera generationer bodde ihop och samboendet naturligt upphörde i och med att den äldre generationen avled. ${ }^{459}$ Syskonhushåll var också en utvidgad familjeform, men de utgjorde en betydligt mer stabil struktur. Det fanns visserligen hushåll där den horisontella utvidgningen 
upphörde och ett syskon ensamt övertog gården. Det vanligaste var emellertid att syskonjordbruket vidmakthölls tills syskonen dog, flyttade eller lade ner jordbruksdriften. I det stora flertalet fall var det inte en övergångsfas innan en kärnfamiljsstruktur etablerades, utan en stabil hushållsformation.

Den definition för syskonhushåll som använts i kapitlet har tagit sin utgångspunkt i den bredare beteckning (frérèche) som återfinns i Hammel och Lasletts hushållstypologi, med tillägg av ett ålderskriterium. ${ }^{460}$ Det grundläggande har inte varit de äktenskapliga förbindelserna utan att hushållet byggde på en syskonrelation. De hushåll som därmed identifierats innehåller två eller flera vuxna syskon, men i övrigt uppvisar de en stor variation. En eller två föräldrar ingick i några hushåll, ibland ytterligare någon äldre släkting. Det fanns enheter med enbart ogifta syskon, men också de där ett eller två hade gift sig. I en del fall bestod hushållet av ett gift syskon med egen familj samt ytterligare ett, två eller tre ogifta syskon. Hade de klassificerats efter äktenskap enligt Hammel och Lasletts modell hade syskonrelationens betydelse skymts.

Mot detta kan emellertid en kritisk fråga riktas: riskerar definitionen att vara för bred? Hade hushåll med ett gift syskon mer likheter med familjejordbruk än med enheter där alla syskon förblev ogifta? Det är en invändning som måste tas på allvar. Om ett syskon gifte sig och skaffade familj fanns ofta en möjlig efterträdare på gården, vilket inte var lika självklart om alla syskon förblev ogifta. Även om dessa hushåll därmed i vissa avseenden liknade familjejordbruk, menar jag att de till syvende och sist måste räknas som syskonjordbruk. Det särpräglade för dem var att flera syskon i vuxen ålder bodde tillsammans. Syskonhushåll med ett gift syskon var därtill ett lika nytt fenomen som att ogifta syskon tog över gemensamt. ${ }^{461}$ De två typerna utvecklades parallellt. Det talar slutligt för att betrakta dem som varianter av samma företeelse.

Det här kapitlet kastar nytt ljus över delundersökningarna i kapitel 2 och 3 . Tillväxtperioden för syskonjordbruk - grovt sett 1870-1930 - stämmer väl överens med analysen av enkäterna i kapitel 3. När frågan om samägda jordbruksfastigheter dök upp i den nationella debatten under 1950-talet speglade det en utveckling 
som redan hade nått - eller rättare sagt passerat - sin topp. Om enbart ägandeförhållandena analyseras framgår emellertid inte syskonjordbrukens omfattning. Många enheter innehades av flera arvingar, men det var också vanligt att jorden formellt ägdes av ett syskon samtidigt som flera bodde kvar. När samägda fastigheter under 1900-talets andra hälft ökade i omfattning förefaller det inte heller ha berott på att syskonhushållen blev fler. Trenden var snarare att de blev färre. Dessutom förändrades deras karaktär. Syskonhushållets storlek krympte, vilket hänger samman med att systrar och föräldrar allt mer sällan ingick. Men också jordbruksstrukturen förändrades och de kvarvarande bröderna, som blev allt äldre, återfanns i större utsträckning på mindre jordbruk.

Förändringarna över tid kan kopplas till de olika alternativ som arvingarna ställdes inför. Under 1900-talets första hälft fanns det syskongårdar längs hela skalan av jordbrukare, från verkliga småbruk till bärkraftiga storjordbruk. Det säger sig självt att både förutsättningarna och alternativen skilde sig mycket åt. Att antalet kvarboende syskon steg med gårdens storlek antyder att arbetskraftsbehovet spelade en viktig roll för syskonhushållets uppkomst. För att driva de större gårdarna krävdes ännu stora arbetsinsatser och alternativet att lämna landsbygden för att söka arbete på annat håll tedde sig sannolikt mindre lockande på sådana enheter. Strategierna tycks snarare ha varit inriktade på att bevara egendomen inom släkten. I sin studie av Nederländerna pekar Richard Paping på att denna strävan märktes tydligare på större egendomar och även i Sverige blev det över tid vanligare att större gårdar gick i släkten. ${ }^{462}$ På många mindre gårdar - där de till antalet flesta syskongårdarna återfanns - var steget bort från jordbruket sannolikt mindre. Attraktiviteten i att lämna gården för att söka sin lycka på annat håll kan dock tänkas ha varierat över tid. Både 1920- och 1930-talet präglades av återkommande kriser som tog sig uttryck i stigande arbetslöshet och sjunkande jordbrukspriser. ${ }^{463}$ För många blev det sannolikt en trygghet att ha en fot i jordbruket och i övrigt åta sig andra sysslor när tillfälle gavs. Att syskonjordbruken mellan 1910 och 1930 blev avsevärt vanligare i småbrukarsocknarna stöder en sådan tolkning. Därigenom finns det skäl att understryka den 
förmåga till anpassning som enligt A.V. Tjajanov kännetecknade bondejordbruket. Ett jordbruk var en tillgång som gjorde det möjligt att agera på olika sätt för att möta samhällsförändringarna.

Handlingsalternativen var emellertid inte desamma för alla arvingar. Även om det successivt öppnade sig yrkesmöjligheter för kvinnor var det främst män som kunde söka sig till yrken utanför jordbruket. Istället fanns en tendens att göra det husliga arbetet till en yrkesidentitet, och en kvarboende syster tycks i ökad utsträckning ha betraktats som en hushållerska. Baserat på minnesuppteckningar från kvinnor födda i början av 1900-talet menar Yvonne Hirdman att jordbrukarhemmen länge präglades av en patriarkal ordning där det var brukligt att döttrars arbetskraft utnyttjades. Hon konstaterar att "med flickor i huset fick man gratis pigor - ibland i åratal" och exemplifierar med berättelser från flera kvinnor som "fastnade" $i$ föräldrahemmets slit eftersom deras plats ansågs vara att hjälpa till hemma. Hirdman understryker de svårigheter som många kvinnor känt inför att ens försöka bryta sig fri. ${ }^{464}$ Mot denna bakgrund är frågan varför systrarna ändå försvann från syskonjordbruken efter 1950. En förklaring är sannolikt ekonomisk. Från 1930-talet minskade antalet husligt anställda i Sverige, vilket speglar framväxten av en industri- och servicesektor med bättre lönevillkor och högre status. Det fanns allt fler möjligheter för en ung ogift kvinna att försörja sig utanför gården. Även andra förhållanden spelade in. Sølvi Sogner pekar på hur synen på det husliga arbetet förändrades och frihet, jämlikhet och oberoende blev viktigare värden. ${ }^{465}$ För döttrar på efterkrigstidens jordbruk var alternativet att bo kvar och sköta hushållet åt en bror inte särskilt lockande.

Kvinnors pliktkänsla och önskan att leva upp till förväntningar kan ha varit avgörande för att 1900-talets syskonjordbruk etablerades. Det faktum att många syskonjordbruk även inkluderade en åldrande moder kan ha förstärkt en sådan plikt. Om konsekvensen av att bryta upp och flytta var att modern ensam fick sköta hushållssysslorna bör det ha hämmat utflyttningsplanerna, särskilt för döttrar. Det finns emellertid ingen anledning att betrakta pliktkänslan som en könsfråga. Bakom många mäns kvarblivande i syskonhushållen fanns sannolikt också ett slags moraliskt tvång. Söners flytt kan 
exempelvis på liknande sätt ha hämmats om konsekvensen blivit att fadern ensam måst driva gården vidare.

Som framgått i detta kapitel befolkades syskonjordbruken av flera individer med olika positioner: bröder och systrar men också föräldrar och ingifta. Förhållandena dem emellan har jag i detta kapitel bara kunnat teckna med breda penseldrag utifrån hushållets sammansättning. För att komma vidare krävs uppgifter om hur de fungerade i praktiken. Det undersöker jag i nästa kapitel. 